\title{
DARPP-32, A Dopamine- and Adenosine 3':5'-Monophosphate-Regulated Phosphoprotein: Regional, Tissue, and Phylogenetic Distribution
}

\author{
Hugh C. Hemmings, Jr. and Paul Greengard \\ Laboratory of Molecular and Cellular Neuroscience, The Rockefeller University, New York, New York 10021
}

Rabbit antisera and mouse monoclonal antibodies have been prepared to bovine DARPP-32 (dopamine- and adenosine $3^{\prime}: 5^{\prime}$ monophosphate-regulated phosphoprotein, $\left.M_{\mathrm{r}}=32,000\right)$, and used to study its regional, tissue, and phylogenetic distributions. The antibodies, none of which distinguished between dephospho-D ARPP-32 and phospho-DARPP-32, were characterized and used to develop a sensitive and specific radioimmunoassay for DARPP-32. The radioimmunoassay, in conjunction with immunolabeling of SDS/PAGE transfers and immunoprecipitation of phosphorylated tissue extracts, was used to measure immunoreactive DARPP-32 in microdissected regions of rat CNS, in peripheral nervous and non-nervous tissues, and in CNS tissue from various animal species.

The distribution of DARPP-32 was generally consistent with the interpretation that it is localized primarily to dopaminoceptive cells that possess dopamine-sensitive adenylate cyclase (D-1 dopamine receptors coupled to adenylate cyclase). Within the rat CNS, DARPP-32 was most highly concentrated in the basal ganglia. DARPP-32 was present in neostriatum from all six mammalian species tested (mouse, rat, guinea pig, rabbit, cow, and rhesus monkey) at concentrations of from 96 to $144 \mathrm{pmol} /$ mg total protein, which constituted from 0.22 to $0.32 \%$ of the total protein. DARPP-32 was also identified at low levels in several peripheral tissues, including choroid plexus, parathyroid cells, adrenal chromaffin cells, posterior pituitary gland, pineal gland, and superior cervical sympathetic ganglion. A phylogenetic survey was carried out of proteins immunologically related to DARPP-32 in nervous tissue from nonmammalian species. DARPP-32-like proteins were identified in dopaminoceptive brain regions from representative members of the amniote vertebrate classes (birds and reptiles), while none was identified in dopaminoceptive brain regions from representative members of the anamniote vertebrate classes (bony fishes and amphibians)

Received Aug. 2, 1985; revised Oct. 28, 1985; accepted Oct. 30, 1985.

This work was supported by United States Public Health Service grants MH 39327 and MH 40899 , and by a grant from the McKnight Foundation. H.C.H. was supported by National Institutes of Health Medical Scientist Training Program Fellowship GM 07205-08. We wish to thank Barbara Hornung (Hybridoma Facility, Department of Pathology, Yale University School of Medicine) for assistance in the preparation of the monoclonal antibodies, Dr. Ivar Walaas (The Rockefeller University) for carrying out the rat brain microdissection, Nina Taggart (The Rockefeller University) for help in performing some of the radioimmunoassays, Dr. Angus Nairn (The Rockefeller University) for gifts of purified protein phosphatase inhibitor-I and G-substrate, and Drs. Edward Brown (Harvard Medical School), Leonard Kaczmarek (Yale University School of Medicine), Tamas Bartfai (Arrhenius Laboratorium, University of Stockholm), Charles Ouimet (The Rockefeller University), Gail Burd (The Rockefeller University), John Haycock (The Rockefeller University), Eliot Ohlstein (Smith, Kline \& French Laboratories), Michael Goy (Harvard Medical School), and Suzanne Garen (Harvard Medical School) for providing some of the tissues used in this study.

Correspondence should be addressed to H. C. Hemmings, Jr., Box 296, The Rockefeller University, 1230 York Avenue, New York, NY 10021.

Copyright (c) 1986 Society for Neuroscience $0270-6474 / 86 / 051469-13 \$ 02.00 / 0$ or in nervous tissue from representative members of several invertebrate classes.

The stimulation of adenylate cyclase activity by dopamine acting at D-1 dopamine receptors (Kebabian and Calne, 1979) is believed to result in physiological changes that are mediated by the activation of cAMP-dependent protein kinase and the concomitant phosphorylation of specific substrate proteins (for reviews, see Hemmings et al., 1986a; Nairn et al., 1985; Nestler et al., 1984). A marked variation has been demonstrated in the regional distribution of a distinct subset of neuronal substrate proteins for cAMP-dependent protein kinase in rat CNS (Walaas et al., 1983b, c). At least seven of these substrate proteins, six soluble and one particulate, were found to be highly enriched in the forebrain basal ganglia, regions of the brain that receive many dopamine-containing axon terminals (for review, see Lindvall and Björklund, 1978) and that contain relatively high dopamine-sensitive adenylate cyclase activities (for reviews, see Iversen, 1975, 1977; Miller and McDermed, 1979). The state of phosphorylation of one of the soluble phosphoproteins, which exhibited a relative molecular weight $\left(M_{\mathrm{r}}\right)$ of 32,000 on SDS/ PAGE, was found to be regulated by dopamine and by the cAMP analog 8-bromo-cAMP in slices prepared from rat caudatoputamen (Walaas and Greengard, 1984; Walaas et al., 1983a). For these reasons, this phosphoprotein was termed DARPP-32 for dopamine- and $\mathrm{c} A \mathrm{MP}$-regulated $p$ hosphoprotein, $M_{\mathrm{r}}=32,000$ (for reviews, see Hemmings et al., 1986a-c; Walaas et al., 1985).

The purification and biochemical characterization of DARPP32 from bovine caudate nucleus has recently been reported (Hemmings et al., 1984a-d; Williams et al., 1986). Enzymological studies have indicated that DARPP-32 is a potent inhibitor of the catalytic subunit of the broad specificity enzyme protein phosphatase-1 (Hemmings et al., 1984a). Inhibition of protein phosphatase- 1 by the dopamine- and cAMP-stimulated phosphorylation of DARPP-32 may be an important component of the biochemical mechanisms involved in producing some of the neurophysiological effects of dopamine acting at D-1 dopamine receptors on dopaminoceptive cells.

We now report the production and characterization of rabbit antiserum and mouse monoclonal antibodies to DARPP-32 and the use of these antibodies to develop a detergent-based radioimmunoassay (RIA) for DARPP-32. This RIA has been used to determine quantitatively the regional distribution of DARPP32 in rat brain and to study its tissue and species distribution. The results obtained using the RIA have been substantiated qualitatively by immonolabeling and by immunoprecipitation techniques. The regional, tissue, and species distributions of DARPP-32 appear to be highly restricted, and to correlate with the distributions of dopaminergic axon terminals and of D-1 dopamine receptors. 


\section{Materials and Methods}

\section{Materials}

$\gamma-{ }^{32} \mathrm{P}-\mathrm{ATP}\left(5-10 \times 10^{7} \mathrm{cpm} / \mathrm{nmol}\right)$ was synthesized by the method of Glynn and Chappell (1964) from dipotassium ATP and carrier-free ${ }^{32} \mathrm{P}$ orthophosphate (New England Nuclear) or purchased from New England Nuclear. Carrier-free ${ }^{125} \mathrm{I}$-sodium iodide $(\sim 17 \mathrm{Ci} / \mathrm{mg}),{ }^{125} \mathrm{I}$-labeled goat anti-rabbit Ig's (2-10 $\mu \mathrm{Ci} / \mu \mathrm{g})$, and ${ }^{125}$ I-labeled goat anti-mouse Ig's $(2-10 \mu \mathrm{Ci} / \mu \mathrm{g})$ were purchased from New England Nuclear. The catalytic subunit of cAMP-dependent protein kinase was purified from bovine heart as described by Kaczmarek et al. (1980). Bovine DARPP-32 was purified to apparent homogeneity by the method of Hemmings et al. (1984b). G-substrate, purified from rabbit cerebellum (Aswad and Greengard, 1981), and inhibitor-1, purified from rabbit skeletal muscle (Hemmings et al., 1984c; Nimmo and Cohen, 1978), were gifts from Dr. Angus Nairn.

Formalin-fixed protein A-bearing Staphylococcus aureus cells (SAC) (Pansorbin), phenylmethylsulfonyl fluoride, and HEPES were purchased from Calbiochem-Behring. Triton X-100 was from J. T. Baker Chemical Co. ATP, NP-40, BSA (Cohn fraction V powder), 8-bromo-cAMP, sodium deoxycholate, hypoxanthine, aminopterin, and thymidine were from Sigma Chemical Co. Leupeptin was from Chemicon (Los Angeles). Chloramine-T was from Eastman Chemical Co. Aprotinin (Trasylol) was from Mobay Chemical Corp. (New York). Dulbecco's modified Eagle's medium and fetal calf serum were from Gibco. Pristane $(2,6,10,14-$ tetramethylpentadecane) was from Aldrich Chemical Co. Polyethylene glycol 1500 was from Gallard-Schlesinger. Freund's adjuvant (complete and incomplete) and $S$. aureus V8 protease were from Miles Laboratories. SDS, Tween 20, and gelatin were from Bio-Rad Laboratories. Nitrocellulose membranes were from Schleicher and Schuell (Keene, NH). Sephadex G-25 (fine) was from Pharmacia. Falcon 3911 Microtest III flexible 96-well assay plates were from Becton Dickinson.

Brains, superior cervical sympathetic ganglia, and adrenal glands from 1- to 3-week-old calves were obtained, packed on ice, from a local slaughterhouse. Normal goat serum and frozen mature rabbit superior cervical sympathetic ganglia were from Pel-Freez Biologicals (Rogers, AK). Male Sprague-Dawley rats (150-200 gm) and BALB/c mice (20$25 \mathrm{gm}$ ) were from Charles River Laboratories. Pseudemys scripta and Rana pipiens were from Connecticut Valley (Southampton, MA). $C y$ prinus carpio was from a local fish market. Serinus canarius was a gift of Dr. Gail Burd, Macaca mulatta brain a gift of Dr. Tamas Bartfai, rabbit vascular tissues a gift of Dr. Eliot Ohlstein, Drosophila melanogaster a gift of Dr. Suzanne Garen, Aplysia californica a gift of Dr. Leonard Kaczmarek, and Homarus americanus a gift of Dr. Michael Goy. Bovine parathyroid glands and isolated bovine parathyroid cells were a gift of Dr. Edward Brown. Isolated bovine adrenal chromaffin cells were a gift of Dr. John Haycock.

\section{Radioiodination of DARPP-32}

DARPP-32 was radioiodinated by the chloramine-T method of Grecnwood et al. (1963). To a vial containing $2 \mathrm{mCi}$ of ${ }^{125} \mathrm{I}$-sodium iodide, $10 \mu \mathrm{l}$ of $0.5 \mathrm{~m}$ sodium phosphate, $\mathrm{pH} 7.4$, was added, followed by the addition of $10 \mu \mathrm{g}$ of purified DARPP-32 in $10 \mu \mathrm{l}$ of $50 \mathrm{~mm}$ sodium phosphate, $\mathrm{pH}$ 7.4. The reaction was initiated by the addition of $10 \mu \mathrm{l}$

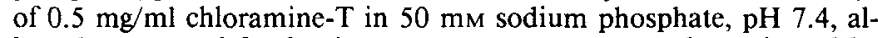
lowed to proceed for $3 \mathrm{~min}$ at room temperature, and terminated by the addition of $10 \mu \mathrm{l}$ of $0.5 \mathrm{mg} / \mathrm{ml}$ sodium metabisulfite and $100 \mu \mathrm{l}$ of $20 \mathrm{mg} / \mathrm{ml}$ sodium iodide, both in $50 \mathrm{~mm}$ sodium phosphate, $\mathrm{pH} 7.4$. To this solution, $60 \mu$ l of column buffer [ $50 \mathrm{~mm}$ sodium phosphate, $\mathrm{pH}$ $7.4,0.5 \%(\mathrm{vol} / \mathrm{vol}) \mathrm{NP}-40,2.5 \mathrm{mg} / \mathrm{ml}$ gelatin] was added, and the reaction mixture removed. The reaction vial was then washed with 100 $\mu$ l of column buffer; the wash was combined with the reaction mixture and then transferred to a $0.7 \times 20 \mathrm{~cm}$ Sephadex G-25 (fine) column equilibrated in column buffer. ${ }^{125}$ I-labeled DARPP-32 was scparated from the reaction mixture by elution with column buffer. Fractions of $0.25 \mathrm{ml}$ were collected, aliquots of each fraction were analyzed for ${ }^{125} \mathrm{I}$ radioactivity using a Micromedic Systems 2/2000 gamma counter, and the peak of ${ }^{125}$ I-labeled DARPP-32 pooled. The ${ }^{125}$ I-labeled DARPP32 was stored in $50 \mu \mathrm{l}$ aliquots at $-20^{\circ} \mathrm{C}$. This procedure resulted in a preparation of ${ }^{125}$ I-labeled DARPP-32 in which $65-85 \%$ of the total radioactivity was contained in intact DARPP-32; the remainder consisted largely of lower-molecular-weight breakdown products. The specific activity was about $50-100 \mu \mathrm{Ci} / \mu \mathrm{g}$ as determined by SDS/PAGE or trichloracetic acid precipitation. From $80-90 \%$ of the radioactivity con- tained in intact ${ }^{125}$ I-labeled DARPP-32 was precipitated by anti-DARPP32 antisera or monoclonal antibodies using the immunoprecipitation procedure described below, suggesting that the iodination procedure had no substantial effect on the immunoreactivity of DARPP-32 (data not shown). DARPP-32 radioiodinated using ${ }^{125}$ I-labeled Bolton-Hunter reagent (Goelz et al., 1981) gave results in the RIA similar to those obtained with DARPP-32 radioiodinated using the chloramine-T method (unpublished observations).

\section{Antibody detection assay}

Rabbit and mouse sera, hybridoma culture supernatants, and ascites fluid were tested for anti-DARPP-32 antibodies by their ability to precipitate ${ }^{125}$ I-labeled DARPP-32 using SAC as an immunoadsorbent (Kessler, 1975). To samples of $70 \mu \mathrm{l}$ in plastic 96-wcll flexible assay plates were added $10 \mu \mathrm{l}$ of $10 \times$ RIA buffer $(0.1 \mathrm{M}$ sodium phosphate, $\mathrm{pH} 7.6,2 \mathrm{M} \mathrm{NaCl}, 0.1 \mathrm{~m}$ EDTA), $10 \mu \mathrm{lof} 10 \%$ (vol/vol) NP-40, and $10 \mu \mathrm{lo}{ }^{125}$ I-labeled DARPP-32 (containing about $10,000 \mathrm{cpm}$ ), followed by a $2-16 \mathrm{hr}$ incubation at $4^{\circ} \mathrm{C}$. Bound ${ }^{125}$ I-labeled DARPP-32 was precipitated with $10 \mu \mathrm{l}$ of a freshly washed $10 \%(\mathrm{wt} / \mathrm{vol})$ suspension of protein A-bearing SAC prepared as described previously (Goelz et al., 1981 ) in NET buffer [ $50 \mathrm{~mm}$ Tris- $\mathrm{HCl}, \mathrm{pH} 7.6,150 \mathrm{~mm} \mathrm{NaCl}, 5 \mathrm{~mm}$ EDTA, $0.02 \%(\mathrm{wt} / \mathrm{vol})$ sodium azide] containing $1 \%(\mathrm{vol} / \mathrm{vol}) \mathrm{NP}-40$ and $25 \mathrm{mg} / \mathrm{ml}$ BSA. Following a $1-2 \mathrm{hr}$ incubation at $4^{\circ} \mathrm{C}$, samples were centrifuged at $1000 \times g$ for $10 \mathrm{~min}$ and the supernatants removed. The SAC pellets were resuspended in NET buffer containing $1 \%(\mathrm{vol} / \mathrm{vol})$ NP-40, centrifuged again, and the amount of immunoprecipitated ${ }^{123}$ Ilabeled DARPP-32 determined. A sample was considered positive for anti-DARPP-32 antibodies when the precipitated radioactivity was greater than twice the nonspecifically precipitated radioactivity (about $100 \mathrm{cpm})$.

\section{Preparation of rabbit anti-DARPP-32 antiserum}

Antiscrum to DARPP-32 was raised in three female New Zealand white rabbits $(1.5-2 \mathrm{~kg})$. After bleeding each rabbit to obtain preimmune serum, each was immunized intradermally at multiple sites over the abdomen with a total of $200 \mu \mathrm{g}$ purified DARPP $-32(0.2 \mathrm{mg} / \mathrm{ml}$ in PBS $)$ emulsified in an equal volume of Freund's complete adjuvant. At 2 and 4 weeks following the first injection, a $100 \mu \mathrm{g}$ dose of DARPP-32 emulsified in Freund's incomplete adjuvant was injected as before. The rabbits were bled by cardiac puncture $10 \mathrm{~d}$ following the final injection. The blood was allowed to clot for $2 \mathrm{hr}$ at room temperature and then overnight at $4^{\circ} \mathrm{C}$, and the serum was recovered by centrifugation at 1000 $\times g$ for $10 \mathrm{~min}$. The antisera obtained were stored at $-70^{\circ} \mathrm{C}$ in small aliquots. The antisera were screened for anti-DARPP-32 antibodies by the antibody-detection assay. The antiserum containing the highest antibody titer (antiserum R2) was used in the present studies.

\section{Preparation of mouse anti-DARPP-32 monoclonal antibodies}

Monoclonal antibodies were produced essentially by the method of Köhler and Milstein (1975). BALB/c, NZB, and AJ mice (two mice each) were immunized with $100 \mu \mathrm{g}$ of purified bovine DARPP-32 in $0.1 \mathrm{ml}$ PBS emulsified with an equal volume of Freund's complete adjuvant by subcutaneous injections into foot pads and over the abdomen. Twelve days following immunization, mice were bled and their sera assayed for anti-DARPP-32 antibodies. Twenty-one days after the initial immunization, mice exhibiting a positive response were boosted intravenously with $100 \mu$ g purified DARPP-32 in PBS. The BALB/c mice were found to exhibit the greatest immune response and were used for the boost and fusion. Three days after the boost, the spleens were removed and the fusion performed by incubating $10^{8}$ spleen cells with $10^{7} \mathrm{Sp} 2 / 0-\mathrm{Ag} 14$ myeloma cells (Shulman et al., 1978) in $50 \%$ polyethylene glycol 1500 for $5 \mathrm{~min}$ at $37^{\circ} \mathrm{C}$. Following the fusion, cells were plated into flat-bottom microtitcr plates in HT medium [Dulbecco's modified Eagle's medium containing $100 \mu \mathrm{M}$ hypoxanthine, $16 \mu \mathrm{M}$ thymidine and $15 \%(\mathrm{vol} / \mathrm{vol})$ fetal calf serum] at a density of $10^{6} \mathrm{cells} /$ well in $0.12 \mathrm{ml}$. After $1 \mathrm{~d}$, HAT medium (HT medium containing $0.8 \mu \mathrm{M}$ aminopterin) was substituted for HT medium in the cultures, and was replaced at $3 \mathrm{~d}$ intervals. After two changes of HAT medium, cells were again fed $\mathrm{HT}$ medium at $3 \mathrm{~d}$ intervals. Two weeks after fusion, culture supernatants were assayed for anti-DARPP-32 antibody. Hybridoma cultures secreting antibodies specific for DARPP-32 were expanded and were then cloned by limiting dilution in flat-bottomed microtiter plates using $\mathrm{BALB} / \mathrm{c}$ thymocytes as a feeder layer. This procedure resulted in 
the production of five stable anti-DARPP-32 antibody-producing clonal hybrid cell lines designated C24-4D7, C24-5a, C24-6a, C24-7a, and C24-13a. The antibody-producing hybrid cell lines were subcloned and expanded, and $2 \times 10^{6}$ cells (in HT medium without serum) per animal were then injected intraperitoneally into $B A L B / c$ recipients primed with pristane $(0.5 \mathrm{ml}$ per mouse). In 1-3 weeks ascites developed and was collected by paracentesis. Cells were removed by centritugation at $1000 \times$ $g$ for $10 \mathrm{~min}$, and the gamma globulin fraction was obtained by precipitation with $45 \%$ saturated ammonium sulfate at $4^{\circ} \mathrm{C}$. After centrifugation at $15,000 \times g$ for $20 \mathrm{~min}$, the protein pellet was dissolved in PBS containing $0.02 \%$ (wt/vol) sodium azide, and dialyzed overnight against the same buffer. The resulting high-titered ascites monoclonal antibodies were stored at $-70^{\circ} \mathrm{C}$ in small aliquots.

\section{Immunolabeling of electrophoretic transfers from SDS/PAGE}

Immunolabeling of proteins solubilized in SDS, separated by SDS/PAGE, and transferred to nitrocellulose membranes was performed by a modification of the procedure described previously (Ouimet et al., 1984). Tissue samples were prepared by homogenization in $20 \mathrm{vol}(\mathrm{ml} / \mathrm{gm})$ of an SDS solution [1\% (wt/vol) SDS, $10 \mu \mathrm{g} / \mathrm{ml}$ leupeptin, and $100 \mu \mathrm{M}$ phenylmethylsulfonyl fluoride] using 10 up-and-down strokes in a glass/ Teflon or glass/glass homogenizer. Purified proteins were dissolved in $1 \%(\mathrm{wt} / \mathrm{vol})$ SDS. Aliquots of the samples were then subjected to SDS/ PAGE and electrophoretically transferred to nitrocellulose membranes $(0.2 \mu \mathrm{m}$ pore size) at $200 \mathrm{~mA}$ for $8-12 \mathrm{hr}$ in $20 \mathrm{~mm}$ Tris- $\mathrm{HCl}, 150 \mathrm{~mm}$ glycine, pH 8.6 , containing $20 \%$ (vol/vol) methanol (Towbin et al., 1979). Following the protein transfer, excess protein binding sites on the nitrocellulose membranes were quenched at $45^{\circ} \mathrm{C}$ in $50 \mathrm{ml}$ of TBS [50 mM Tris- $\mathrm{HCl}, \mathrm{pH} 7.6,150 \mathrm{~mm} \mathrm{NaCl}, 0.05 \%$ (wt/vol) sodium azide] containing $10 \%(\mathrm{vol} / \mathrm{vol})$ normal goat serum and $1 \%(\mathrm{wt} / \mathrm{vol}) \mathrm{BSA}$ for 8-12 hr. Membranes were then incubated at room temperature in 50 $\mathrm{ml}$ of TBS containing $1 \%(\mathrm{vol} / \mathrm{vol})$ normal goat serum, $0.5 \%(\mathrm{wt} / \mathrm{vol})$ $\mathrm{BSA}$, and various dilutions of either the antiserum or monoclonal antibodies for 2-4 hr. Membranes were washed in $50 \mathrm{ml}$ of TBS containing $0.05 \%$ ( $\mathrm{vol} / \mathrm{vol}$ ) Tween 20 (Batteiger et al., 1982) for $20 \mathrm{~min}$, followed by two washes in $50 \mathrm{ml}$ of TBS alone for 20 min each. Radiolabeling of the bound antibodies was performed by incubating the washed membranes in $50 \mathrm{ml}$ of ${ }^{125} \mathrm{I}$-labeled goat anti-rabbit or goat anti-mouse Ig's $\left(10^{5} \mathrm{cpm} / \mathrm{ml}\right)$ in TBS containing $1 \%(\mathrm{vol} / \mathrm{vol})$ normal goat serum and $0.5 \%(\mathrm{wt} / \mathrm{vol}) \mathrm{BSA}$ for $2 \mathrm{hr}$. The sheets were then washed $3 \times 20 \mathrm{~min}$ with $50 \mathrm{ml}$ of TBS containing Tween 20 , followed by a single wash in $50 \mathrm{ml}$ of TBS alone. The sheets were then dried and exposed at $-70^{\circ} \mathrm{C}$ to Kodak X-Omat AR film using a DuPont Lighting Plus intensifying screen.

\section{Immunoprecipitation of phosphorylated tissue extracts}

Crude cytosol was prepared and endogenously phosphorylated using 8-bromo-cAMP and $\gamma_{-}{ }^{32} \mathrm{P}-\mathrm{ATP}$ as described previously by Hemmings et al. (1984b), and acid extracts were prepared and phosphorylated using exogenous catalytic subunit of cAMP-dependent protein kinase and $\gamma-32$ P-ATP as described by Walaas and Greengard (1984). Phosphorylation reactions were terminated by the addition of SDS to a final concentration of $1 \%(\mathrm{wt} / \mathrm{vol})$, followed by heating to $95^{\circ} \mathrm{C}$ for $2 \mathrm{~min}$. Immunoprecipitation was performed at $4^{\circ} \mathrm{C}$ in polypropylene microfuge tubes. An equal volume of a $2 \times$ concentrated buffer solution was added to the SDS-containing samples to yield final concentrations of $20 \mathrm{~mm}$ Tris- $\mathrm{HCl}, \mathrm{pH} 7.6,125 \mathrm{~mm} \mathrm{NaCl}, 50 \mathrm{~mm} \mathrm{NaF}, 10 \mathrm{~mm}$ sodium pyrophosphate, $10 \mathrm{~mm}$ EDTA, $0.5 \%$ SDS, and $2.5 \%$ (vol/vol) NP-40. A 5 $\mu l$ aliquot of a $10 \%$ (wt/vol) SAC suspension in NET buffer containing $25 \mathrm{mg} / \mathrm{ml} \mathrm{BSA}$ was added to the phosphorylated mixture, and incubated for $15 \mathrm{~min}$. The SAC was removed by centrifugation in a Beckman Microfuge 12 at $12,400 \times g$ for $5 \mathrm{~min}$, and the "precleared" supernatant transferred to a second microfuge tube containing anti-DARPP-32 antibody. This solution was vortexed and incubated for 30-90 min. A 50 $\mu \mathrm{l}$ aliquot of SAC was then added, incubated for $15 \mathrm{~min}$, and the suspension centrifuged for $5 \mathrm{~min}$. The supernatant was removed and the pellet resuspended in $200 \mu \mathrm{l}$ of $1 \%$ (wt/vol) SDS, heated to $95^{\circ} \mathrm{C}$ for 5 $\mathrm{min}$, and the suspension centrifuged for $5 \mathrm{~min}$. The supernatant was removed and subjected to a second cycle of immunoprecipitation beginning with the addition of an equal volume of the $2 \times$ concentrated buffer solution as described above. The resulting SAC pellet was washed with $0.5 \mathrm{ml}$ of NET buffer, resuspended in $125 \mu$ l of SDS-containing "stop solution," subjected to SDS/PAGE, and analyzed by autoradiography (Hemmings et al., 1984b).
Competitive nonequilibrium radioimmunoassay for DARP-32

Formalin-fixed SAC were employed as a solid-phase immunoadsorbent in the RIA. Prior to each RIA, the ${ }^{125}$ I-labeled DARPP-32 was precleared with SAC. This was accomplished by adding $100 \mu \mathrm{l}$ of RIA buffer (10 mm sodium phosphate, $\mathrm{pH} 7.6,200 \mathrm{~mm} \mathrm{NaCl}, 10 \mathrm{~mm}$ EDTA) containing $1 \%(\mathrm{vol} / \mathrm{vol}) \mathrm{NP}-40$ to an aliquot of ${ }^{225}$ I-labeled DARPP32 , followed by $20 \mu \mathrm{l}$ of freshly washed SAC in NET buffer containing $25 \mathrm{mg} / \mathrm{ml}$ BSA. This solution was incubated for $30 \mathrm{~min}$ at $4^{\circ} \mathrm{C}$. After centrifugation at $12,400 \times g$ in a Beckman Microfuge 12 for $5 \mathrm{~min}$, the "precleared" supernatant was removed and added to an appropriate volume of RIA buffer containing 1\% (vol/vol) NP-40 to give $5-10 \times$ $10^{3} \mathrm{cpm} / 10 \mu \mathrm{l}$. Using this amount of ${ }^{125}$ I-labeled DARPP-32, various antiserum and monoclonal antibody dilutions were tested to determine the amount of antibody that precipitated $50-60 \%$ of the label in the competition state of the RIA. The final dilution of antiserum R2 used in the RIA was 1:200 and that of monoclonal antibody C24-13a was $1: 100,000$.

The RIA was performed in plastic 96 -well flexible assay plates at $4^{\circ} \mathrm{C}$ in a final volume of $100 \mu$ l. All standards and samples were assayed in triplicate. The individual solutions of standard DARPP-32, of precleared ${ }^{125}$ I-labeled DARPP-32, and of anti-DARPP-32 antibodies were diluted with RIA buffer containing $1 \%$ (vol/vol) NP-40. Standards and samples both contained final concentrations of $0.1 \%(\mathrm{wt} / \mathrm{vol})$ SDS and $1 \%$ (vol/vol) NP-40 (Dimitriadis, 1979). The samples and standards were brought to a final volume of $80 \mu$ l and the precompetition stage of the RIA initiated by the addition of $10 \mu \mathrm{l}$ of an appropriate dilution of the anti-DARPP-32 antibodies followed by gentle shaking of the assay plate for several seconds. After a $12 \mathrm{hr}$ precompetition, $10 \mu \mathrm{l}$ of precleared ${ }^{125}$ I-labeled DARPP-32 was added, again with gentle shaking. After a $1 \mathrm{hr}$ competition, $10 \mu \mathrm{l}$ of prewashed SAC in RIA buffer containing $25 \mathrm{mig} / \mathrm{mil}$ BSA was added, the assay plates were shaken gently, and the samples were incubated for a further $20 \mathrm{~min}$. The assay plates were then centrifuged at $1000 \times g$ for $10 \mathrm{~min}$. The supernatants were removed by inverting and flicking the plates, and the pellets softened by vortexing the plates. The pellets were washed once in $100 \mu \mathrm{l}$ of RIA buffer containing $1 \%$ (vol/vol) NP-40. The wells containing the SAC pellets were cut from the assay plates, and the ${ }^{125} I$ radioactivity measured using a Micromedic Systems 2/2000 gamma counter. Data were analyzed using linear logit-log plots of the competition curves (data not shown).

\section{Preparation of samples for $R I A$}

Rat brain was dissected as described (Walaas et al., 1983b), and the microdissected regions immediately homogenized in an SDS solution $[1 \%(\mathrm{wt} / \mathrm{vol}) \mathrm{SDS}, 10 \mu \mathrm{g} / \mathrm{ml}$ leupeptin, and $100 \mu \mathrm{M}$ phenylmethylsulfonyl fluoride]. For determination of the levels of DARPP-32 in the neostriatum of various mammalian species, and in the nervous systems of various vertebrate and invertebrate species, samples were obtained from freshly killed animals and immediately frozen or homogenized in SDS solution. In some experiments various peripheral tissues were also analyzed. Freshly dissected or quick-frozen tissue samples were homogenized with a glass/Tefion homogenizer in 20 vol of SDS solution. The homogenates were then heated to $95^{\circ} \mathrm{C}$ for $2 \mathrm{~min}$ and sonicated, and insoluble material was removed by centrifugation at $12,400 \times g$ for 10 $\mathrm{min}$. Protein concentrations were determined by a detergent-based Folin reagent assay, using BSA as a standard, after precipitation of protein with sodium deoxycholate and trichloroacetic acid (Peterson, 1977).

\section{Phosphorylation of purified DARPP-32}

DARPP-32 was phosphorylated by incubating purified DARPP-32 in a reaction mixture containing 50 mм HEPES, pH 7.4, 10 mм magnesium acetate, $1 \mathrm{~mm}$ EGTA, $2 \mathrm{ng}$ purified catalytic subunit of cAMPdependent protein kinase and $50 \mu \mathrm{M}$ ATP in a final volume of $100 \mu 1$ at $30^{\circ} \mathrm{C}$ for $60 \mathrm{~min}$ (Hemmings et al., $1984 \mathrm{~b}$, c). As a control, a sample of DARPP-32 was treated identically except that the catalytic subunit was omitted.

\section{Miscellaneous methods}

One-dimensional phosphopeptide mapping using $S$. aureus V8 protease, according to the method of Cleveland et al. (1977), and SDS/PAGE, according to the method of Laemmli (1970), were carried out as described previously (Hemmings et al., 1984b). Two-dimensional phosphopeptide mapping of thermolytic digests and phospho-amino acid 


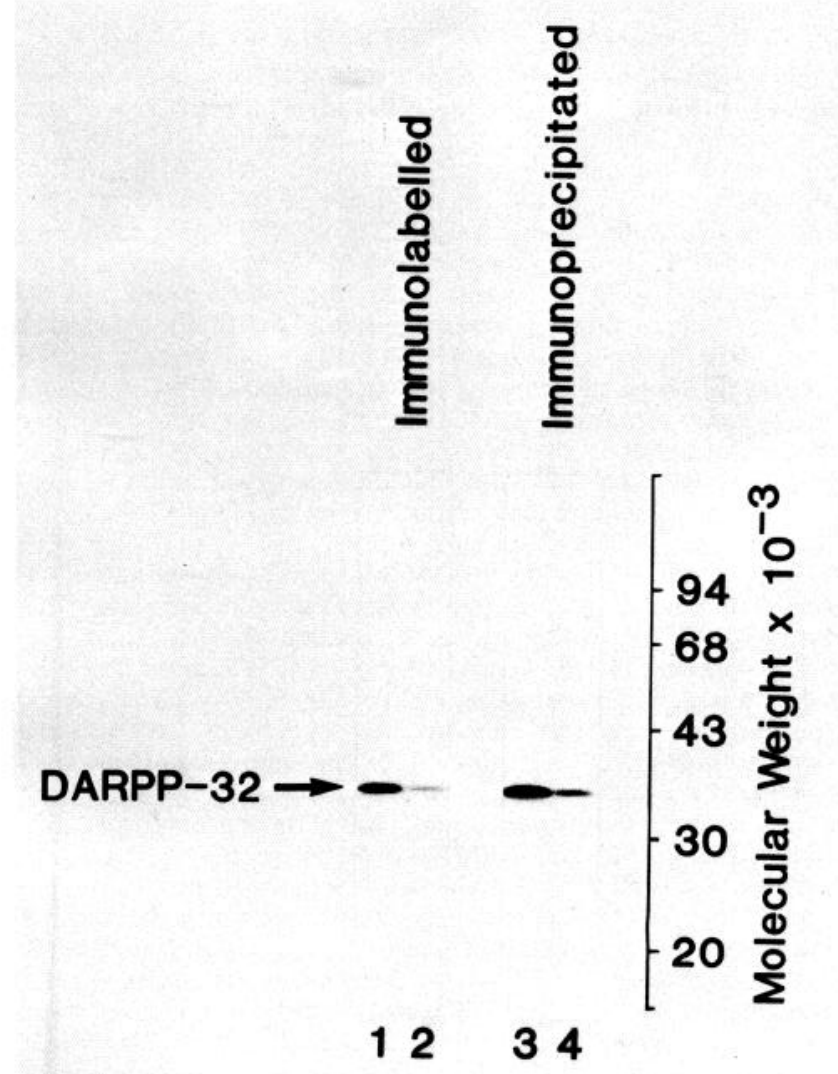

Figure 1. Characterization of specificity of anti-DARPP-32 monoclonal antibody $\mathrm{C} 24-13 \mathrm{a}$ by immunolabeling and immunoprecipitation. Lanes 1 and 2, Samples of rat caudatoputamen and neocortex were dissected from the brain, homogenized in SDS, subjected to SDS/PAGE ( $9 \%$ acrylamide), and electrophoretically transferred to a nitrocellulose membrane as described in Materials and Methods. The nitrocellulose membrane was labeled with a 1:1000 dilution of monoclonal antibody C24-13a, followed by ${ }^{125}$ I-labeled goat anti-mouse Ig's, and analyzed by autoradiography. Lanes 3 and 4, Crude cytosol was prepared from samples of rat caudatoputamen and neocortex and subjected to endogenous phosphorylation with 8-bromo-cAMP and $\gamma^{-32} \mathrm{P}$-ATP, followed by immunoprecipitation with $2 \mu \mathrm{l}$ of monoclonal antibody C24-13a. Immunoprecipitated proteins were subjected to SDS/PAGE ( $9 \%$ acrylamide) and analyzed by autoradiography. For the caudatoputamen samples (lanes 1 and 3) $75 \mu \mathrm{g}$ of total protein were used, while for the neocortex samples (lanes 2 and 4) $150 \mu \mathrm{g}$ of total protein were used.

analyses were performed as described previously (Hemmings et al., 1984c).

\section{Results}

Characterization of DARPP-32 antibodies

All three immunized rabbits and all six immunized mice produced antibodies to DARPP-32. The rabbit serum containing the highest titer of anti-DARPP-32 activity was chosen for further characterization. Only a single band was detected when antiserum R2 was used to immunolabel nitrocellulose membranes to which tissue extracts prepared from bovine caudate nucleus or rat caudatoputamen and separated by SDS/PAGE had been transferred electrophoretically (data not shown). Moreover, antiserum R2 precipitated a single phosphoprotein from bovine caudate nucleus or rat caudatoputamen cytosol phosphorylated by the addition of 8 -bromo-cAMP and $\gamma-{ }^{32} \mathrm{P}$ ATP (data not shown).

Immunized $\mathrm{BALB} / \mathrm{c}$ mice were found to produce the highest titer of anti-DARPP-32 activity and were used to produce monoclonal antibodies by the method of Köhler and Milstein (1975). Characterization of the anti-DARPP-32 monoclonal antibodies using immunolabeling of rat brain proteins separated by SDS/PAGE and transferred to nitrocellulose and immunoprecipitation of phosphorylated rat brain extracts was performed. Both techniques resulted in the identification of a single protein band using either monoclonal antibody C24-13a (Fig. 1) or any of the four other monoclonal antibodies (Ouimet et al., 1984; and data not shown). The amount of DARPP-32 detected was greater in caudatoputamen than in neocortex. Similar results were obtained with homogenates of bovine caudate nucleus and neocortex (data not shown). The immunolabeling of a single protein band in either rat or bovine brain homogenates and the immunoprecipitation of a single phosphoprotein from the mixture of cAMP-stimulated phosphoproteins present in crude cytosol preparations strongly suggest that both the antiserum and the monoclonal antibodies prepared against DARPP32 are specific for DARPP-32. However, the possibility of immunologic reactivity with a protein not efficiently transferred to nitrocellulose or having an apparent molecular weight on SDS/PAGE identical to that of DARPP-32 cannot be ruled out.

\section{Radioimmunoassay of DARPP-32}

Using antiserum R2, a detergent-based nonequilibrium RIA of DARPP-32 was developed based on the method described by Goelz et al. (1981) for the quantitation of synapsin I. The inclusion of a 10-fold weight excess of the nonionic detergent NP-40 over the ionic detergent SDS in the RIA permitted homogenization of tissue samples in $1 \%$ SDS, which reduced proteolysis during sample preparation and reduced background radioactivity without disruption of the antigen-antibody complex (Dimitriadis, 1979). The use of a competitive nonequilibrium assay involving sequential saturation conditions in which the antibody was preincubated with the samples for $12 \mathrm{hr}$ before the ${ }^{125} \mathrm{I}$-labeled DARPP-32 was added increased the sensitivity of the assay and reduced overall incubation times.

The competition curves obtained using rabbit antiserum R2 to bovine DARPP-32 and ${ }^{125}$ I-labeled bovine DARPP-32 are shown in Figure 2. The range of sensitivity of the assay was from about 10 to $100 \mathrm{fmol}$ of DARPP-32. Fifty percent displacement $\left(B / B_{0}=0.5\right)$ was obtained with about $29 \mathrm{fmol}$ of DARPP-32. The phospho- and dephospho-forms of DARPP32 were equipotent in the RIA (data not shown). Bovine caudate nucleus solubilized in $1 \%$ SDS produced a competition curve parallel to that of purified bovine DARPP-32 and resulted in essentially complete displacement of ${ }^{125}$ I-labeled bovine DARPP32. However, rat caudatoputamen solubilized in $1 \%$ SDS did not produce a competition curve parallel to that of purified bovine DARPP-32, nor did it result in complete displacement of ${ }^{125}$ I-labeled bovine DARPP-32 (Fig. 2). Similar results showing lack of complete displacement were also obtained for mouse, guinea pig, and rabbit neostriatum homogenates (data not shown). The competition curves of neostriatum homogenates using antiserum $\mathrm{R} 2$ revealed heterogeneity between bovine and nonbovine DARPP-32. This was manifest in the absence of parallel competition curves, indicating heterogeneous antibody affinity, and in partial cross-reactivity (less than complete displacement), indicating heterogeneity in the specificity of the antiserum for different determinants on the immunogen (Berzofsky and Schechter, 1981).

The partial cross-reactivity of the nonbovine forms of DARPP32 observed in the RIA using antiserum R2 made this RIA unsuitable for quantitation of DARPP-32 in species other than cow. True cross-reactivity is expected for certain homogeneous antibodies to a single determinant (Berzofsky and Schechter, 1981), a condition that applies to monoclonal antibodies. The monoclonal antibodies to bovine DARPP-32 were therefore 


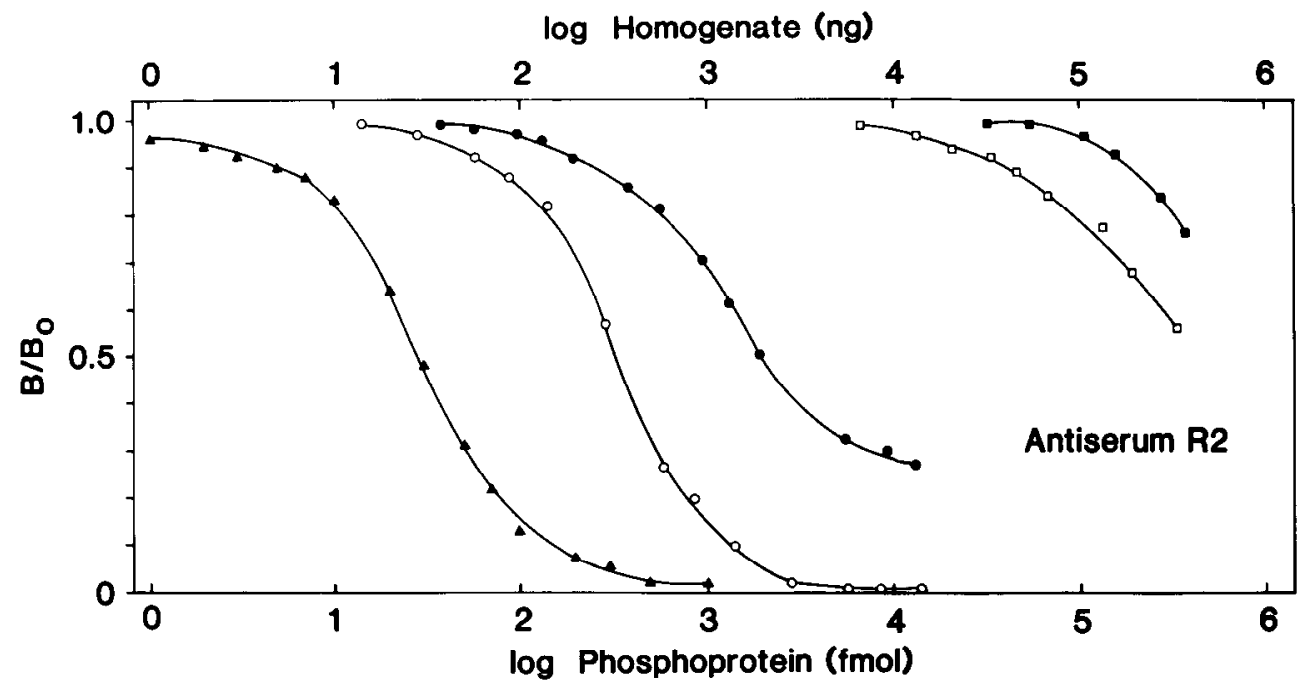

Figure 2. Competition curves using antiserum R2 for RIA of purified bovine DARPP-32 $(\mathbf{\Lambda})$, bovine caudate nucleus homogenate $(O)$, rat caudatoputamen homogenate $(\bullet)$, purified rabbit skeletal muscle protein phosphatase inhibitor- $1(\Pi)$, and purified rabbit cerebellum G-substrate ( $\square$ ) with ${ }^{125} \mathrm{I}$-labeled bovine dephospho-DARPP-32. Abscissa, Log of total of DARPP-32, inhibitor-1, or G-substrate in assay (lower) or log of total homogenate protein from bovine caudate nucleus or rat caudatoputamen (upper); ordinate, ratio of ${ }^{125}$-labeled DARPP-32 bound in the sample $(B)$ to ${ }^{125}$ l-labeled DARPP32 bound with no DARPP-32 added $\left(B_{0}\right)$, both corrected for nonspecific binding.

tested for true cross-reactivity to nonbovine DARPP-32 using the RIA technique. Of the five monoclonal antibodies prepared, antibody C24-13a resulted in the most sensitive RIA. As can be seen in Figure 3, the range of sensitivity of the RIA using antibody C24-13a was from about 5 to 80 fmol of DARPP-32. Fifty percent displacement $\left(B / B_{0}=0.5\right)$ was obtained with about $18 \mathrm{fmol}$ of DARPP-32. The phospho- and dephospho-forms of DARPP-32 were equipotent in the RIA (data not shown). Bovine caudate nucleus solubilized in $1 \%$ SDS produced a competition curve parallel to that of the purified bovine DARPP32 and resulted in complete displacement of ${ }^{125}$ I-labeled bovine DARPP-32. Comparison of the competition curve obtained using a homogenate of rat caudatoputamen (Fig. 3) with that of purified bovine DARPP-32 also revealed parallel curves with essentially complete displacement of ${ }^{125}$ I-labeled bovine DARPP32. Homogenates of neostriatum from mouse, guinea pig, rabbit, rhesus monkey, canary, and turtle also produced parallel competition curves with essentially complete displacement of ${ }^{125}$ I-labeled bovine DARPP-32 (data not shown), comparable to the curves shown for rat or bovine neostriatum (Fig. 3), indicating true cross-reactivity of the homologous nonbovine forms of DARPP-32. The RIA employing monoclonal antibody C24-13a was therefore chosen for the quantitative determinations of DARPP-32 levels reported in this study. The RIA employing antiserum R2 was also used to analyze bovine tissue samples and to screen nonbovine species for the presence of
DARPP-32; the results from these assays were in good agreement with those obtained using monoclonal antibody C24-13a.

Immunologic cross-reactivity of DARPP-32 with other phosphoproteins

Previous studies have indicated many similarities between DARPP-32 and protein phosphatase inhibitor-1 (inhibitor-1), a potent inhibitor of protein phosphatase-1, and G-substrate, a Purkinje cell-specific phosphoprotein (Hemmings et al., 1984a, b, d; Williams et al., 1986). Inhibitor-1 and G-substrate were tested for immunologic cross-reactivity with DARPP-32 using the RIA (Figs. 2, 3). Limited displacement of ${ }^{125}$ I-labeled DARPP32 was observed for both phosphoproteins in the RIA at very high concentrations, indicating some degree of immunological relatedness between these three phosphoproteins. Purified inhibitor- 1 began to exhibit competition in the RIA at about 10 pmol with antiserum R2 and at about 5 pmol with monoclonal antibody C24-13a. Purified G-substrate also competed in the RIA but was less potent than inhibitor-1; G-substrate began to exhibit competition in the RIA at about 100 pmol with antiserum R2 and at about $20 \mathrm{pmol}$ with monoclonal antibody C2413a. The greater immunoreactivity of inhibitor- 1 than of G-substrate in the RIA is consistent with the greater similarity in the known amino acid sequences of DARPP-32 and inhibitor-1 compared to G-substrate (Aitken et al., 1981, 1982; Hemmings et al., 1984d; Williams et al., 1986). The potency of either of

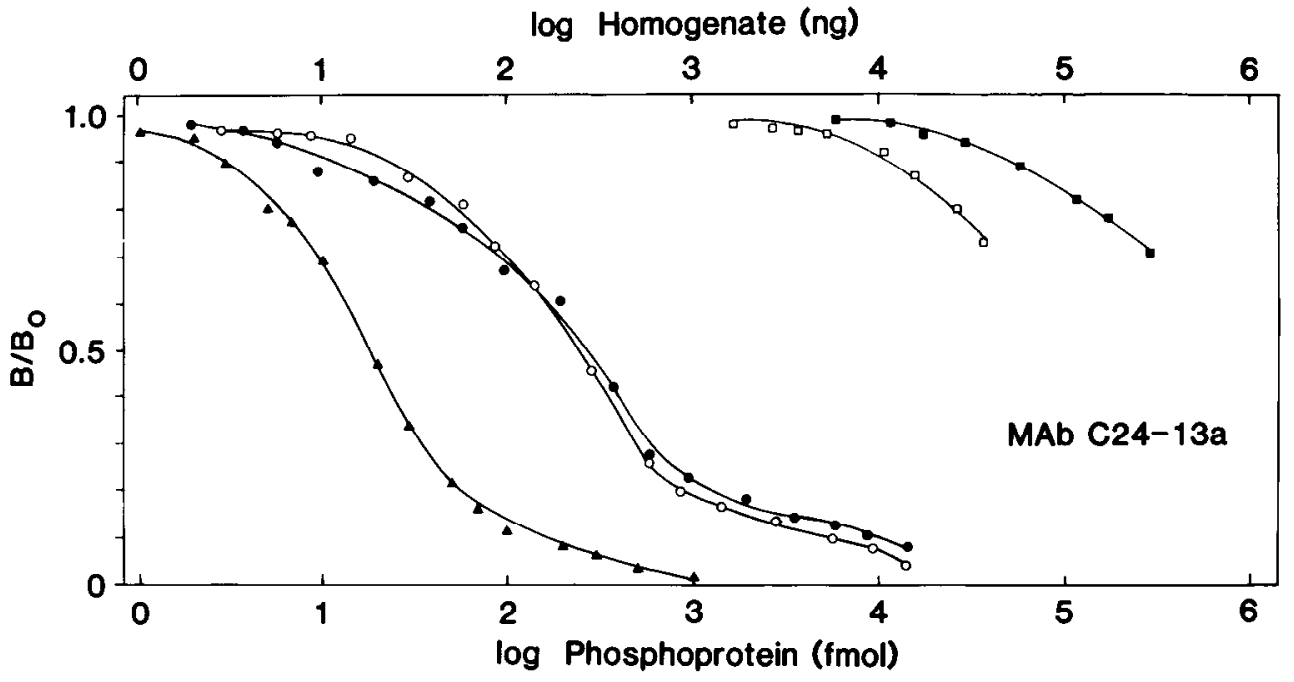

Figure 3. Competition curves using monoclonal antibody C24-13a for RIA of purified bovine DARPP-32 (४), bovine caudate nucleus homogenate $(\mathrm{O})$, rat caudatoputamen homogenate $(\bullet)$, purified rabbit skeletal muscle protein phosphatase inhibitor-1 ( $\square$ ), and purified rabbit cerebellum $G$-substrate (ם) with ${ }^{125}$ I-labeled bovine dephosphoDARPP-32. For explanation of abscissa and ordinate, see legend to Figure 3. 


\begin{tabular}{lc}
\hline Table 1. Regional distribution of DARPP-32 in rat CNS \\
& $\begin{array}{l}\text { Immunoreactive } \\
\text { DARPP-32 } \\
\text { (pmol/mg total protein) }\end{array}$ \\
Region & $133.6 \pm 11.0$ \\
\hline Substantia nigra & $129.5 \pm 9.4$ \\
Caudatoputamen & $112.3 \pm 7.0$ \\
Globus pallidus & $77.3 \pm 14.6$ \\
Olfactory tubercle & $60.3 \pm 12.4$ \\
Nucleus accumbens & $16.5 \pm 3.2$ \\
Thalamus & $14.8 \pm 2.6$ \\
Cerebellum & $8.0 \pm 3.2$ \\
Cerebral cortex & $7.4 \pm 2.1$ \\
Hippocampus & $6.3 \pm 3.0$ \\
Retina & $6.0 \pm 1.0$ \\
Frontal cortex & $5.0 \pm 1.0$ \\
Hypothalamus & $4.3 \pm 1.2$ \\
Amygdala & $3.4 \pm 0.8$ \\
Septum & $2.2 \pm 0.6$ \\
Pons/medulla & $1.1 \pm 0.6$ \\
Olfactory bulb & $0.6 \pm 0.4$ \\
Spinal cord &
\end{tabular}

Values represent the means \pm SEM of at least three experiments, each employing two tissue concentrations assayed in triplicate, calculated using a molecular mass of 22,59l Da obtained by amino acid sequencing of bovine brain DARPP-32 (Williams et al., 1986).

these phosphoproteins in the DARPP-32 RIA was at least three orders of magnitude less than that of DARPP-32, indicating a high degree of specificity of the RIA for DARPP-32. Synapsin I, a neuronal phosphoprotein unrelated to DARPP-32 (Ueda and Greengard, 1977), did not exhibit any competition in the RIA at up to $1 \mathrm{nmol}$ (data not shown).

The cross-reactivity of the antibodies to DARPP-32 with inhibitor-1 were further analyzed using the immunolabeling and immunoprecipitation techniques. Neither antiserum R2 nor monoclonal antibody C24-13a immunolabeled $5 \mu \mathrm{g}$ of purified inhibitor-1, whereas they did immunolabel $0.010 \mu \mathrm{g}$ of purified DARPP-32 (data not shown). Likewise, neither antibody preparation immunoprecipilated $10 \mu \mathrm{M}$ purified phospho-inhibitor1 , while both immunoprecipitated $0.05 \mu \mathrm{M}$ purified phosphoDARPP-32 (data not shown). These results further support the specificity of the antibodies to DARPP-32 in the presence of experimentally observable tissue concentrations of inhibitor-1, which is present at a concentration of $1.5 \mu \mathrm{M}$ in rabbit skclctal muscle (Nimmo and Cohen, 1978).

\section{Regional distribution of $D A R P P-32$ in rat $C N S$}

The distribution of DARPP-32 in 17 microdissected regions of rat CNS was studied using the RIA (Table 1). DARPP-32 was found to be highly enriched in the substantia nigra, caudatoputamen (neostriatum), and globus pallidus, which contained greater than $100 \mathrm{pmol}$ of DARPP-32/mg of tissue protein. Intermediate DARPP-32 levels were measured in the olfactory tubercle and nucleus accumbens, which contained 77 and 60 pmol of DARPP-32/mg of tissue protein, respectively, while the other regions examined contained less than $17 \mathrm{pmol}$ of DARPP- $32 / \mathrm{mg}$ of tissue protein. The presence of DARPP-32 in each of the 17 CNS regions tested was confirmed by immunolabeling and by immunoprecipitation which resulted in the detection of a single immunoreactive protein with an $M_{\mathrm{r}}=$ 32,000 in each region.

Quantitation of DARPP-32 in the neostriatum of mammalian species of various orders

The amounts of DARPP-32 in neostriatal extracts prepared from six mammalian species representing four orders were mea-
Table 2. Concentrations of DARPP-32 in the nenstriatum of mammalian species of various orders

\begin{tabular}{lll} 
& \multicolumn{2}{l}{$\begin{array}{l}\text { Immunoreactive } \\
\text { DARPP-32 }\end{array}$} \\
\cline { 2 - 3 } & $\begin{array}{l}\text { (pmol/mg } \\
\text { total protein) }\end{array}$ & $\begin{array}{l}\text { (\% of total } \\
\text { protein) }\end{array}$ \\
\hline Order & & \\
\hline $\begin{array}{l}\text { Rodentia } \\
\quad \text { Mouse (Mus musculus) }\end{array}$ & $102.5 \pm 11.7$ & 0.23 \\
$\quad$ Rat (Rattus norvegicus) & $130.7 \pm 10.6$ & 0.29 \\
$\quad$ Guinea pig (Cavia porcellis) & $110.7 \pm 8.9$ & 0.25 \\
Lagomorpha & & \\
$\quad$ Rabbit (Oryctolagus cuniculus) & $143.6 \pm 9.6$ & 0.32 \\
Artiodactyla & & \\
$\quad$ Cow (Bos taurus) & $97.4 \pm 8.8^{a}$ & 0.22 \\
Primates & & \\
$\quad$ Rhesus monkey (Macaca mulatta) & $95.8 \pm 12.6$ & 0.22 \\
\hline
\end{tabular}

Values represent the means \pm SEM of at least three experiments, each employing two tissue concentrations assayed in triplicate, calculated using a molecular mass of 22,591 Da obtained by amino acid sequencing of bovine brain DARPP-32 (Williams et al., 1986).

${ }^{a}$ Agrees with value determined by RIA using antiserum R2 (101.2 $\pm 6.3 \mathrm{pmol} /$ $\mathrm{mg}$ total protein)

sured by use of the RIA (Table 2). DARPP-32 immunoreactivity was detected in the neostriatum of each of the six species at concentrations ranging from 96 to $144 \mathrm{pmol}$ of DARPP-32/mg of total protein. DARPP-32 was highly concentrated in the neostriatum, constituting from 0.22 to $0.32 \%$ of the total neostriatal protein.

Immunoprecipitation of phosphorylated acid extracts allowed the identification of the phosphorylated acid-soluble proteins cross-reacting with the antibodies to DARPP-32 and supported the results obtained by RIA. The six immunoprecipitated phosphoproteins exhibited similar mobilities on SDS/PAGE, which corresponded to apparent $M_{\mathrm{r}}$ values of $30,000-34,000$ (Fig. 4). The antibodies precipitated a doublet from the rabbit extract, both components of which yielded identical one-dimensional phosphopeptide maps after proteolysis with $S$. aureus V8 protease, and identical two-dimensional phosphopeptide maps after proteolysis with thermolysin (data not shown). Furthermore, the phosphoproteins immunoprecipitated from each of the five nonbovine species yielded one-dimensional phosphopeptide maps using $S$. aureus V8 protease and two-dimensional phosphopeptide maps using thermolysin that were similar to those previously published for bovine DARPP-32 (Hemmings et al., $1984 b, c)$. Phosphothreonine was the only phosphorylated amino acid in each immunoprecipitated phosphoprotein (data not shown). The apparent $M_{\mathrm{r}}$ values determined by SDS/PAGE of the phosphoproteins immunoprecipitated from mouse, rat, guinea pig, rabbit, cow and rhesus monkey neostriatum were about $34,000,34,000,30,000,32,000 / 30,000,32,000$, and 32,000 , respectively (Fig. 4).

\section{Quantitation of DARPP-32 in various peripheral tissues}

The RIA for DARPP-32 was also used to analyze various peripheral non-nervous and nervous tissues (Table 3 ). No competition was observed when up to $25 \mu \mathrm{g}$ of total protein from the peripheral non-nervous tissues lung, liver, heart, kidney, spleen, pancreas, skeletal muscle, or smooth muscle were assayed. These results indicate that DARPP-32, if present in these tissues, would comprise less than 0.2 pmol of DARPP $-32 / \mathrm{mg}$ of total tissue protein. A very low level of DARPP-32 was detected in bovine parathyroid cells. These results were confirmed by immunolabeling and immunoprecipitation (data not 


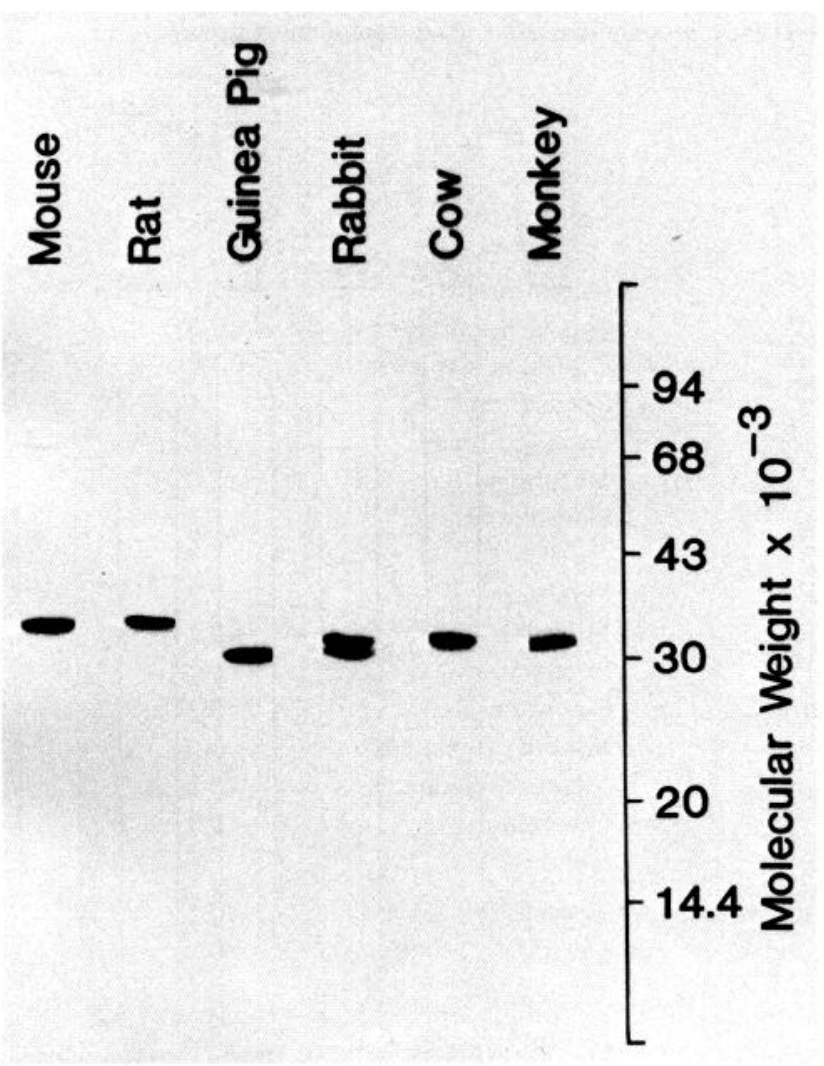

Figure 4. Immunoprecipitation of DARPP-32 from phosphorylated extracts prepared from various mammalian neostriata. Crude cytosol was prepared from samples of the neostriata of the mammalian species indicated, and acid extracts prepared and phosphorylated using the catalytic subunit of cAMP-dependent protein kinase and $\gamma-{ }^{32} \mathrm{P}-\mathrm{ATP}$ The phosphorylated proteins were immunoprecipitated with $2 \mu \mathrm{l}$ of monoclonal antibody $\mathrm{C} 24-13 \mathrm{a}$. The immunoprecipitated proteins were then subjected to SDS/PAGE ( $10 \%$ acrylamide) and analyzed by autoradiography.

shown). The fact that no immunoreactivity was observed in skeletal muscle by RIA, immunolabeling, or immunoprecipitation in spite of the presence of relatively high amounts (1.5 $\mu \mathrm{M})$ of inhibitor-1 in this tissue (Nimmo and Cohen, 1978) further attests to the specificity of the DARPP-32 immunoassay procedures.

Various peripheral nervous tissues were also analyzed for DARPP-32. Both bovine and rabbit superior cervical sympathetic ganglion contained DARPP-32. Although DARPP-32 was not detected in the anterior pituitary gland (adenohypophysis), low levels were measured in the posterior pituitary (neurohypophysis). Low levels of DARPP-32 were also measured in rat pineal gland, bovine adrenal medulla, isolated bovine adrenal chromaffin cells, and bovine choroid plexus. The identification of DARPP-32 in superior cervical sympathetic ganglion, isolated adrenal chromaffin and parathyroid cells, posterior pituitary, adrenal medulla, and choroid plexus by RIA was confirmed by immunolabeling and immunoprecipitation and by phosphopeptide mapping (data not shown).

\section{Phylogenetic survey of DARPP-32 immunoreactivity}

The RIA for DARPP-32 was used to carry out a survey of DARPP-32 immunoreactivity in the CNS of representative vertebrate and invertebrate species (Table 4), which included members of four classes of subphylum Vertebrata (bony fishes, amphibians, reptiles, and birds) and members of two invertebrate phyla-Arthropoda (Homarus and Drosophila) and Mollusca (Aplysia). No DARPP-32 immunoreactivity was detected when
Table 3. Distribution of DARPP-32 in various tissues

\begin{tabular}{ll} 
& $\begin{array}{l}\text { Immunoreactive } \\
\text { DARPP-32 } \\
\text { (pmol/mg total } \\
\text { protein) }\end{array}$ \\
Tissue & $<0.2$ \\
Lung, rat & $<0.2$ \\
Liver, rat & $<0.2$ \\
Heart, rat & $<0.2$ \\
Kidney, rat & $<0.2$ \\
Spleen, rat & $<0.2$ \\
Pancreas, rat & $<0.2$ \\
Skeletal muscle, rat & $<0.2$ \\
Skeletal muscle, rabbit & $<0.2$ \\
Splenic artery, rabbit & $<0.2$ \\
Mesenteric artery, rabbit & $<0.2$ \\
Renal artery, rabbit & $<0.2$ \\
Aorta, rabbit & $<0.2$ \\
Parathyroid gland, cow & $0.3 \pm 0.1$ \\
Isolated parathyroid cells, cow & $<0.2$ \\
Anterior pituitary, rat & $1.6 \pm 0.4$ \\
Posterior pituitary, rat & $6.0 \pm 2.2$ \\
Pineal gland, rat & $2.0 \pm 0.3$ \\
Superior cervical ganglion, rabbit & $3.8 \pm 0.5$ \\
Superior cervical ganglion, cow & $2.1 \pm 0.4$ \\
Adrenal medulla, cow & $2.9 \pm 0.6$ \\
Isolated adrenal chromaffin cells, cow & $6.7 \pm 2.1$ \\
Choroid plexus from lateral ventricle, cow & \\
& \\
\hline
\end{tabular}

Values represent the means \pm SEM of at least three experiments, each employing two tissue concentrations assayed in triplicate, calculated using a molecular mass of 22,591 Da obtained by amino acid sequencing of bovine brain DARPP-32 (Williams et al., 1986).

CNS samples containing up to $25 \mu \mathrm{g}$ of total protein from members of the two invertebrate phyla or from two of the vertebrate classes - the bony fishes (Osteichthyes) and the amphibians ( $\mathrm{Am}$ phibia) - were analyzed. However, significant levels of DARPP32 were observed in CNS samples from members of both the reptilian (Reptilia) and bird (Aves) classes. In the turtle, the highest amount of DARPP-32 immunoreactivity was measured in the basal forebrain; lower amounts were measured in the midbrain and dorsal neocortex. In the canary, DARPP-32 immunoreactivity was highly enriched in the paleostriatum; lower amounts were detected in the neostriatum and cerebellum.

The DARPP-32 immunoreactivity in the vertebrate species was further characterized by immunolabeling and immunoprecipitation. No immunolabeled proteins or immunoprecipitated phosphoproteins were detected in crude cytosol or acid extracts prepared from carp or frog CNS (Figs. 5, 6). However, both immunolabeling (Fig. 5) and immunoprecipitation of cAMPstimulated phosphoproteins (Fig. 6) identified DARPP-32-immunoreactive proteins in turtle and canary brain extracts, with apparent $M_{\mathrm{r}}$ values of 44,000 and 32,500 , respectively. The rank orders of the levels of the DARPP-32 identified in various turtle and canary brain regions by immunolabeling and immunoprecipitation agreed with those obtained using the RIA. One-dimensional phosphopeptide mapping using $S$. aureus V8 protease of the immunoprecipitated phosphoproteins obtained from turtle basal forebrain and canary paleostriatum yielded phosphopeptide maps similar to that of bovine DARPP-32 (data not shown).

\section{Discussion}

The RIA employing monoclonal antibody C24-13a was sensitive to DARPP-32 in the range of 5-80 fmol per assay well. 
Table 4. Phylogenetic survey of DARPP-32 immunoreactivity using radioimmunoassay

\begin{tabular}{|c|c|c|}
\hline Class & Region & $\begin{array}{l}\text { Immunoreactive } \\
\text { DARPP-32 (pmol/mg } \\
\text { total protein) }\end{array}$ \\
\hline \multicolumn{3}{|l|}{ Subphylum Vertebrata } \\
\hline \multicolumn{3}{|l|}{ Amniotes } \\
\hline \multirow[t]{4}{*}{ Aves (Serinus canarius, canary) } & Paleostriatum & $85.0 \pm 10.4$ \\
\hline & Caudal neostriatum & $10.6 \pm 4.7$ \\
\hline & Rostral neostriatum & $7.9 \pm 2.5$ \\
\hline & Cerebellum & $2.4 \pm 1.0$ \\
\hline \multirow[t]{3}{*}{ Reptilia (Pseudemys scripta, turtle) } & Basal forebrain & $37.1 \pm 5.4$ \\
\hline & Midbrain & $12.6 \pm 3.6$ \\
\hline & Dorsal neocortex & $7.7 \pm 2.2$ \\
\hline \multicolumn{3}{|l|}{ Anamniotes $^{\alpha}$} \\
\hline \multirow{3}{*}{ Amphibia (Rana pipiens, frog) } & Cerebrum & $<0.2$ \\
\hline & Midbrain & $<0.2$ \\
\hline & Cerebellum & $<0.2$ \\
\hline \multirow[t]{4}{*}{ Osteichthyes (Cyprinus carpio, carp) } & Cerebrum & $<0.2$ \\
\hline & Midbrain/thalamus & $<0.2$ \\
\hline & Mesencephalon & $<0.2$ \\
\hline & Cerebellum & $<0.2$ \\
\hline \multicolumn{3}{|l|}{ Phylum Arthropoda ${ }^{a}$} \\
\hline Crustacea (Homarus americanus, lobster) & Nervous system & $<0.2$ \\
\hline Insecta (Drosophila melanogaster, fly) & Head & $<0.2$ \\
\hline \multicolumn{3}{|l|}{ Phylum Mollusca ${ }^{a}$} \\
\hline Gastropoda (Aplysia californica, sea snail) & Nervous system & $<0.2$ \\
\hline
\end{tabular}

The sensitivity of the RIA was enhanced by using a nonequilibrium assay in which the antibody was preincubated with the samples prior to a short incubation with the labeled tracer (sequential saturation conditions), as has been demonstrated for the measurement of creatine kinase isoenzymes (Van Steirteghem et al., 1978). The antibodies did not distinguish between phospho- and dcphospho-DARPP-32; thus, the RI $\Lambda$ provides an estimate of the total immunoreactive DARPP-32 present, in contrast to the phosphorylation assay, which measures only the amount of dephospho-DARPP-32 (Walaas and Greengard, 1984). This suggests that monoclonal antibody C24-13a does not recognize the phosphorylation site or a determinant affected by phosphorylation of DARPP- 32 .

The RIA for DARPP-32 was used to survey the distribution of DARPP-32 immunoreactivity in microdissected regions of rat CNS. The highest concentrations of immunoreactive DARPP32 were found in substantia nigra, caudatoputamen, and globus pallidus, and slightly lower concentrations were found in olfactory tubercle and nucleus accumbens. The concentrations of DARPP-32 in these five brain regions were approximately 10 fold higher than those in the other CNS regions examined. Four of the regions containing the highest levels of DARPP-32 (substantia nigra, caudatoputamen, nucleus accumbens, and olfactory tubercle) are also characterized by high dopamine-sensitive adenylate cyclase activities (Clement-Cormier et al., 1974; Horn et al., 1974; Kebabian and Saavedra, 1976; Kebabian et al., 1972; Krieger et al., 1977; Phillipson and Horn, 1976; Premont et al., 1976; Spano et al., 1976; for reviews, see Iversen, 1975, 1977; Miller and McDermed, 1979), by a high density of dopaminergic axon terminals or dendrites (Cheramy et al., 1981; Fuxe, 1965; Hökfelt et al., 1977; Lindvall and Björklund, 1974;
Ungerstedt, 1971; for reviews, see Björklund and Lindvall, 1984; Lindvall and Björklund, 1978; Moore and Bloom, 1978), by high dopamine concentrations (Brownstein et al., 1974; Versteeg et al., 1976), and by high levels of tyrosine hydroxylase activity (Bacopoulos and Bhatnagar, 1977), the rate-limiting enzyme in dopamine biosynthesis. The caudatoputamen, nucleus accumbens, and olfactory tubercle receive most of the terminals of the nigrostriatal and mesolimbic dopamine system neurons (Lindvall and Björklund, 1978), while the globus pallidus and substantia nigra are the main anatomical targets of these three dopamine-innervated brain regions.

Light- and electron-microscopic immunocytochemistry (Ouimet et al., 1983, 1984) and lesion studies (Walaas and Greengard, 1984) have been used to show that DARPP-32 is present in the cytoplasm of cell bodies, dendrites, axons, and axon terminals of the medium-sized spiny neurons of the caudatoputamen and nucleus accumbens and in the axons and axon terminals of the striatonigral and striatopallidal fibers, which originate from the medium-sized spiny neurons and terminate in the substantia nigra pars reticulata, globus pallidus, and ventral pallidum. The large amounts of DARPP-32 found in the substantia nigra and globus pallidus by RIA are probably due to its presence in the axons and axon terminals of striatonigral and striatopallidal neurons. In addition to constituting the terminal field of the dopaminoceptive striatal neurons, the globus pallidus also receives a modest dopaminergic innervation (Lindvall and Björklund, 1979). Similarly, dopamine is released in the substantia nigra pars reticulata, presumably from the dendrites of dopamine neurons (Cheramy et al., 1981). In summary, DARPP-32 is enriched in dopamine-innervated regions of the basal ganglia, probably in dopaminoceptive cells that contain 


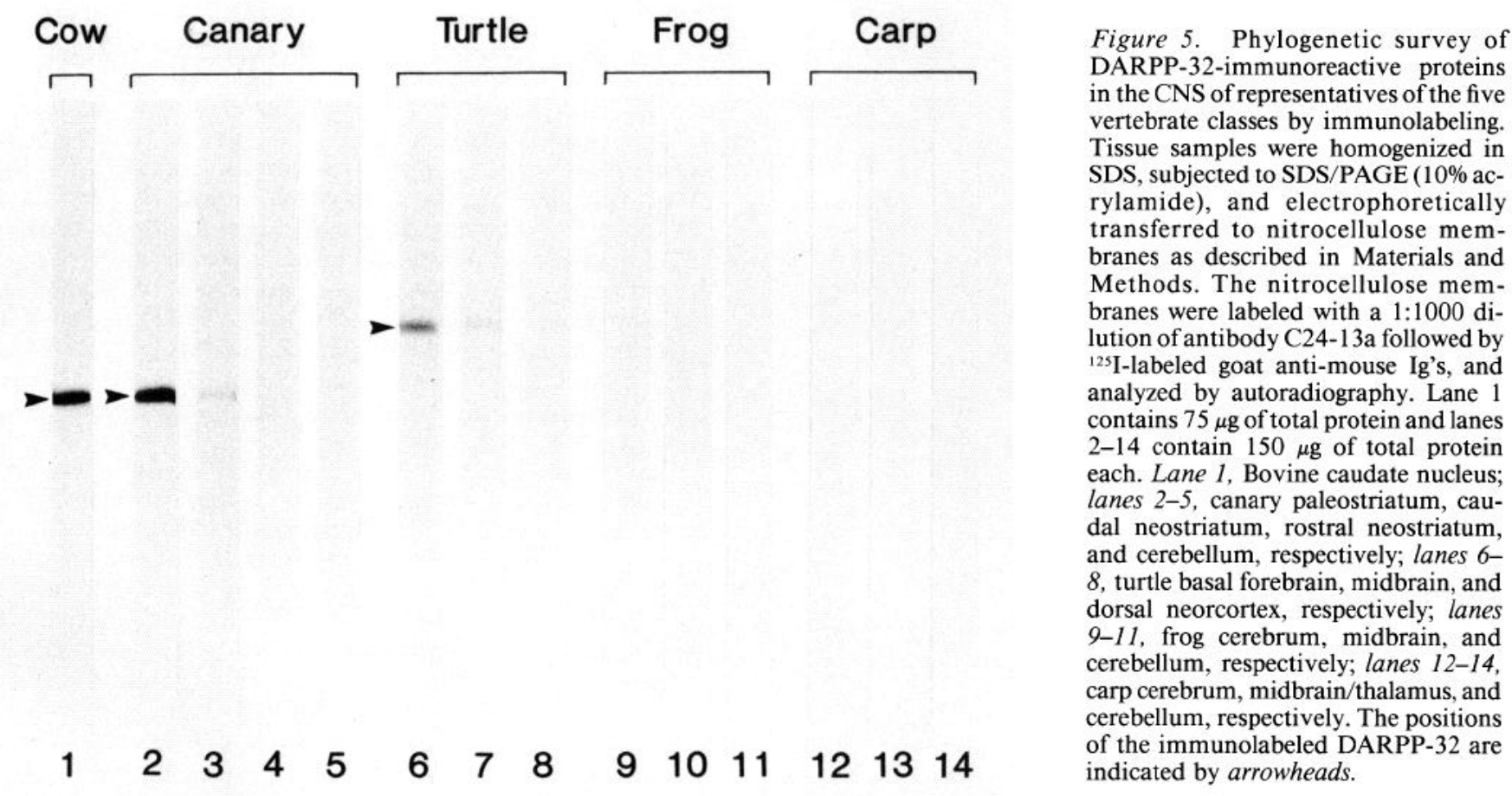

D-1 dopamine receptors (Ouimet et al., 1983, 1984; Walaas and Greengard, 1984).

The distribution of DARPP-32 in other regions of the brain is also generally consistent with its localization in dopaminoceptive cells possessing D-1 dopamine receptors (for reviews, see Hemmings et al., 1986b; Walaas et al., 1986). There is now considerable evidence for the existence of a restricted dopamine input to the hippocampus (Ishikawa et al., 1982; Verney et al., 1985), where a dopamine-sensitive adenylate cyclase has also been demonstrated (Dolphin et al., 1979). The relatively low levels of DARPP-32 in some brain regions, such as the amygdala and hypothalamus, which are known to contain dense dopaminergic innervation and dopamine-sensitive adenylate cyclase activity (Clement-Cormier and Robison, 1977), may be explained by DARPP-32 being located in restricted populations of cells (Ouimet et al., 1984). The low concentration of DARPP32 in frontal cortex appears to reflect a diffuse dopaminergic innervation primarily to the basal layers of this brain region, again with the concomitant localization of DARPP-32 to a subpopulation of neurons. The slightly higher levels of DARPP-32 in whole cerebral cortex may reflect the inclusion of several regions of the limbic cortex (cingulate, piriform, and entorhinal cortex) that contain DARPP-32 as determined by immunofluorescent labeling (Ouimet et al., 1984). These regions of the cerebral cortex also receive most of the cortical dopaminergic innervation and contain relatively high dopamine-sensitive adenylate cyclase activities (Tassin et al., 1978). Dopamine is present in vertebrate retina, where it appears to function as a neurotransmitter released by a subclass of intrinsic amacrine cells (Ehinger, 1977; Kramer, 1971), and dopamine-sensitive adenylate cyclase has been identified in homogenates of both rat and bovine retina (Brown and Makman, 1972). The septum, pons/medulla, olfactory bulb, and spinal cord, which contain low levels of DARPP-32 immunoreactivity, also contain low levels of dopamine (Holzbauer and Sharman, 1979) and, in some cases, identifiable dopaminergic axon terminals (Lindvall and Björklund, 1978). The thalamus and cerebellum contain appreciable amounts of DARPP-32 but little dopamine (Versteeg et al., 1976) and apparently few dopaminergic axon terminals (Lindvall and Björklund, 1978).

Although the distribution of DARPP-32 in the CNS measured by RIA (this study) or by a phosphorylation assay (Walaas and Greengard, 1984) roughly parallels the distribution of dopamine-containing axon terminals, and more closely parallels the distribution of dopaminoceptive neurons possessing dopaminesensitive adenylate cyclase (D-1 dopamine receptors coupled to adenylate cyclase), it is not quantitatively proportional to either the amount of dopaminergic innervation or of dopamine-sensitive adenylate cyclase activity in a particular region. There are several factors that may contribute to this disparity. First, in those dopamine-innervated regions that possess only D-2 dopamine receptors, DARPP-32 should not be present. Second, as a cytosolic protein (Walaas and Greengard, 1984), the amount of DARPP-32 in some brain regions may reflect the combined cell volume of the dopaminoceptive cells rather than the amount of dopamine input or dopamine-sensitive adenylate cyclase present. Third, apparent anomalies may exist when D-1 dopaminoceptive cells in one brain region, which contain DARPP32 and receive a dopamine input, send processes, which contain DARPP-32, to another brain region that does not receive a dopamine input. Fourth, recent studies have demonstrated that the distribution of D-2 dopamine receptors within the brain may be greater than that known for dopaminergic innervation (Martres et al., 1985), a condition that may pertain to D-1 dopamine receptors as well. The monoaminergic neurotransmitters can probably diffuse a considerable distance through the brain (Reader et al., 1979), suggesting the possibility that in these cases DARPP-32 may identify certain neurons that are "physiologically" postsynaptic to dopamine, even in the absence of direct synaptic contact (Ouimet et al., 1984; Schmitt, 1984). Fifth, in some brain regions, a minor dopaminergic input may have escaped detection using the available methods. And finally, 


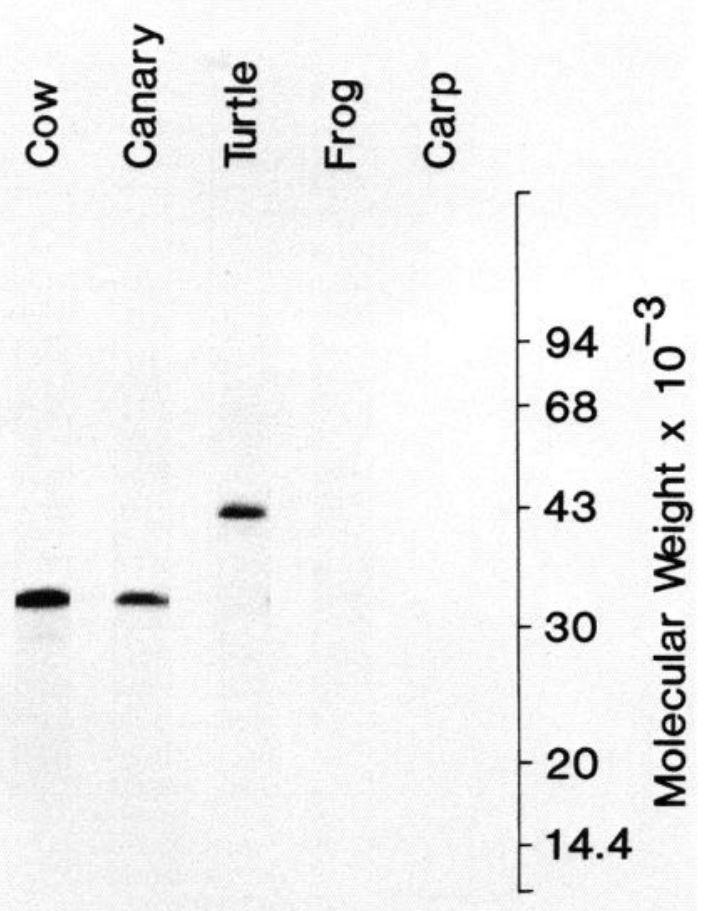

Figure 6. Identification by immunoprecipitation of phosphorylated DARPP-32-immunoreactive proteins in the CNS of representatives of the five vertebrate classes. Crude cytosol was prepared from samples of bovine caudate nucleus, canary paleostriatum, turtle basal forebrain, frog cerebrum, and carp cerebrum and subjected to endogenous phosphorylation with 8-bromo-cAMP and $\gamma-{ }^{32} \mathrm{P}$-ATP followed by immunoprecipitation with $2 \mu \mathrm{l}$ of monoclonal antibody C24-13a. Immunoprecipitated proteins were subjected to SDS/PAGE (10\% acrylamide) and analyzed by autoradiography. Samples of cytosol containing 100 $\mu \mathrm{g}$ of total protein (cow and canary) or $200 \mu \mathrm{g}$ of total protein (turtle, frog, and carp) were used.

DARPP-32 may in some cases be able to act as an effector for neurotransmitters other than dopamine (e.g., norepinephrine) acting through cAMP, as suggested by the presence of DARPP32 in the cerebellum.

The amounts of DARPP-32 determined by RIA in various regions of rat brain are higher than those determined by use of a phosphorylation assay (Walaas and Greengard, 1984), although the rank order of the levels is comparable. Possible explanations for the lower values obtained in the phosphorylation assay include: (1) interference by protein kinase inhibitors and/or inaccessibility of the protein kinase to DARPP-32 as a result of binding or occlusion, (2) the presence of phosphorylated DARPP-32 in the samples, and (3) endogenous protease or protein phosphatase activity. Our experience suggests that measurements made with the RIA more accurately reflect DARPP32 levels.

Phosphoproteins immunologically related to bovine DARPP32 were identified in mouse, rat, guinea pig, rabbit, and rhesus monkey brain, and were present in comparable amounts. DARPP- 32 constituted from 0.22 to $0.32 \%$ of the total protein in the neostriatum of these six species representing four mammalian orders, an amount comparable to that of synapsin I, a well-characterized synaptic vesicle-associated phosphoprotein that appears to be involved in the regulation of neurotransmitter release (De Camilli et al., 1983; Huttner et al., 1983; Llinàs et al., 1985) and that has also been shown to exist in several mammalian orders (Goelz et al., 1985). The apparent $M_{\mathrm{r}}$ values of the homologous forms of DARPP-32, as determined by SDS/ PAGE, differed slightly.
Immunocytochemical studies of the cellular localization of DARPP-32 in rat caudotoputamen have revealed that DARPP32 is present in at least $60 \%$ of the medium-sized spiny neurons (Ouimet et al., 1983, 1984), which make up approximately $96 \%$ of the neurons in this nucleus (Groves, 1983). Assuming that these neurons make up about $50 \%$ of the volume of the caudatoputamen, the estimated concentration of DARPP-32 within these neurons is on the order of 20-50 $\mu \mathrm{M}$. This concentration is about $10 \times$ higher than the apparent $K_{\mathrm{m}}$ values of DARPP32 for phosphorylation by cAMP-dependent protein kinase (Hemmings et al., 1984c) and for dephosphorylation by protein phosphatase-2B (calcineurin; King et al., 1984), and $10^{4} \times$ higher than the apparent $K_{\mathrm{i}}$ value $(0.5-2.2 \mathrm{~nm})$ of phospho-DARPP32 for inhibition of protein phosphatase- 1 in vitro (Hemmings et al., 1984a), suggesting that these reactions would be favorable kinetically in vivo.

In contrast to brain, most peripheral tissues examined contained less than $0.2 \mathrm{pmol}$ DARPP-32/mg tissue protein as determined by RIA. Of the non-nervous tissues tested, only adrenal medulla, isolated bovine adrenal chromaffin and parathyroid cells, and choroid plexus contained detectable levels of DARPP-32 by RIA, immunolabeling and immunoprecipitation. Dopamine-sensitive adenylate cyclase has not been detected in bovine adrenal chromaffin cells (Serck-Hanssen et al., 1972; Gutman and Boonyaviroj, 1979). However, bovine parathyroid cells contain both D-1 dopamine receptors (Brown et al., 1977) and cAMP-dependent protein kinase (Brown and Thatcher, 1982), which may be involved in the regulation of DARPP-32 phosphorylation through cAMP. The presence of DARPP-32 in the choroid plexus may be related to the physiological effects of dopamine observed in this neuroectodermal secretory epithelium (Townsend et al., 1984), although a dopamine-sensitive adenylate cyclase has not been conclusively demonstrated (Nathanson, 1980). Recently, DARPP-32 has been demonstrated in another neuroectodermal secretory epithelium, the nonpigmented epithelial layer of the ciliary body (Stone et al., 1985, 1986).

DARPP-32 was not detected in kidney or in any of the peripheral vascular tissues tested. Renal vasculature and certain other vascular tissues are known to contain a cardiovascular dopamine receptor, known as the DA-1 dopamine receptor, which is coupled to the stimulation of adenylate cyclase and which is similar to the D-1 dopamine receptor of nervous and endocrine tissues in its pharmacological properties (for review, see Stoof and Kebabian, 1984). The absence of detectable DARPP-32 in kidney and peripheral vascular tissues may indicate a difference in the postreceptor mechanisms of D-1 and DA-1 dopamine receptors, or the amounts present in these tissues may be below the sensitivity of the RIA.

Studies of peripheral nervous tissues demonstrated that DARPP-32 was present in the posterior pituitary, which receives a dopamine input (Björklund et al., 1973) and possesses both D-1 and D-2 dopamine receptors. In contrast, DARPP32 was not detectable in the anterior pituitary, which has only D-2 dopamine receptors (Kebabian and Calne, 1979); this provides an example of a dopamine-innervated tissue that possesses only D-2 dopamine receptors and does not contain DARPP32 .

DARPP-32 was demonstrated in both rabbit and bovine superior cervical sympathetic ganglion by RIA, immunolabeling, and immunoprecipitation. This ganglion contains dopamine in its small, intensely fluorescent cells (Björklund et al., 1970), and a dopamine-sensitive adenylate cyclase has been demonstrated also (Kebabian and Greengard, 1971), suggesting a role for DARPP-32 in mediating some of the effects of dopamine in this tissue.

The RIA was also used to carry out a phylogenetic survey of DARPP-32 distribution. Phosphoproteins antigenically related 
to DARPP-32 were detected by RIA, immunolabeling and immunoprecipitation in specific regions of bird and reptile CNS. The apparent $M_{\mathrm{r}}$ of turtle DARPP-32 was significantly higher than that of any other species tested, presumably due to differences in its primary structure. Relatively strong DARPP-32 immunoreactivity was observed in canary paleostriatum and turtle basal forebrain. The results from canary (Burd et al., 1985; and G. Burd, H. C. Hemmings, Jr., J. Heinz, P. Greengard and F. Nottebohm, unpublished observations) and turtle (C. C. Ouimet, H. C. Hemmings, Jr., G. Burd and P. Greengard, unpublished observations) have been confirmed by immunocytochemical studies.

In both canary and turtle (as in rat), the brain regions that contain the highest levels of DARPP-32 (paleostriatum and basal forebrain, respectively) are regions that receive major catecholaminergic inputs and are thought to be homologous to mammalian neostriatum (Parent et al., 1984; Reiner et al., 1984). The avian paleostriatum, the acknowledged homolog of the mammalian neostriatum (Brauth et al., 1978), receives a major ascending catecholaminergic projection, probably dopaminergic. The turtle striatum, which is included in the basal forebrain dissection, also receives an ascending catecholaminergic input consisting primarily of dopamine (Juorio, 1973; Parent, 1979). The cellular localization of DARPP-32 in these species by immunocytochemical methods should yield valuable information concerning the phylogenetic development and comparative anatomy of D-1 dopaminoceptive neurons in the vertebrates, particularly within the basal ganglia.

No DARPP-32 immunoreactivity was detected by RIA, immunolabeling, or immunoprecipitation in CNS tissue from the two anamniote vertebrate classes, the amphibians and bony fishes, or in nervous tissue from three invertebrate classes, using either antiserum R2 or monoclonal antibody C24-13a. This could be due either to antigenic differences between the DARPP32 of these species and bovine DARPP-32, the presence of levels of DARPP-32 below the sensitivity of the assay techniques, or the absence of a DARPP-32 homolog in these species. The presence of DARPP-32 in the amniote vertebrates (reptiles, birds, and mammals) and its apparent absence in anamniote vertebrates (bony fishes and amphibians) parallels the striking differences in the organization and relative development of the central catecholamine systems in these two vertebrate groups (see Parent et al., 1984). Thus, in the amniotes there is hypertrophy of the midbrain catecholamine neuronal population along with an increased dopaminergic projection to the striatum. The results of the study of the phylogenetic distribution of DARPP32 in a limited number of species suggest that the phylogenetic development of DARPP-32 may correspond to that of the mesotriatal dopamine pathways. It will be important to test this hypothesis by the analysis of additional species from various vertebrate orders.

RIA provides a sensitive assay for the direct measurement of DARPP-32 levels and is free of many of the potential problems associated with quantitative measurements by the phosphorylation assay. The regional distribution of DARPP-32 in the mammalian CNS determined by RIA exhibits a remarkable correlation with the distribution of dopamine-containing axon terminals and dopamine-sensitive adenylate cyclase, although several possible exceptions involving less well characterized brain regions have been observed. Its distribution in peripheral tissues may also correspond to the distribution of dopaminoceptive neurons possessing $\mathrm{D}-1$ dopamine receptors, although the amounts are considerably lower than those found in the CNS. The phylogenetic distribution of DARPP-32 appears to parallel the evolutionary development of the midbrain dopaminergic projection to the striatum. The determination of the normal distribution and concentration of DARPP-32 in various brain regions and peripheral tissues by immunochemical methods provides the necessary basis for examining alterations in its concentration resulting from various pharmacological treatments and pathological processes.

\section{References}

Aitken, A., T. Bilham, P. Cohen, D. Aswad, and P. Greengard (1981) A specific substrate from rabbit cerebellum for guanosine $3^{\prime}, 5^{\prime}$-monophosphate-dependent protein kinase. III. Amino acid sequences at the two phosphorylation sites. J. Biol. Chem. 256: 3501-3506.

Aitken, A., T. Bilham, and P. Cohen (1982) Complete primary structure of protein phosphatase inhibitor-1 from rabbit skeletal muscle. Eur. J. Biochem. 126: 235-246.

Aswad, D. W., and P. Greengard (1981a) A specific substrate from rabbit cerebellum for guanosine $3^{\prime}, 5^{\prime}$-monophosphate-dependent protein kinase. I. Purification and characterization from rabbit cerebellum. J. Biol. Chem. 256: 3487-3493.

Bacopoulos, N. G., and R. K. Bhatnager (1977) Correlation between tyrosine hydroxylase activity and catecholamine concentration and turnover in brain regions. J. Neurochem. 29: 639-643.

Batteiger, B., W. J. Newhall, and R. B. Jones (1982) The use of Tween 20 as a blocking agent in the immunological detection of proteins transferred to nitrocellulose membranes. J. Immunol. Methods 55: 297-307.

Berzofsky, J. A., and A. N. Schechter (1981) The concepts of crossreactivity and specificity in immunology. Mol. Immunol. 18: 751763.

Björklund, A., and O. Lindvall (1984) Dopamine-containing systems in the CNS. In Handbook of Chemical Neurounatomy. Vol. 2: Classical Transmitters in the CNS, Part I, A. Björklund and T. Hökfelt, eds., pp. 55-122, Elsevier, Amsterdam.

Björklund, A., L. Cegrell, B. Falck, M. Ritzen, and E. Rosengren (1970) Dopamine-containing cells in sympathetic ganglia. Acta Physiol. Scand. 78: 334-338.

Björklund, A., R. Y. Moore, A. Nobin, and U. Stenevi (1973) The organization of tubero-hypophyseal and reticulo-infundibular catecholamine neuron systems in the rat brain. Brain Res. 51:171-191.

Brauth, S. E., J. L. Ferguson, and C. A. Kitt (1978) Prosencephalic pathways related to the paleostriatum of the pigeon (Columba livia). Brain Res. 147: 205-221.

Brown, E. M., and J. G. Thatcher (1982) Adenosine 3':5'-monophosphate (cAMP)-dependent protein kinase and the regulation of parathyroid hormone release by divalent cations and agents elevating cyclic AMP in dispersed bovine parathyroid cells. Endocrinology 110: 1374-1380.

Brown, E. M., R. J. Carroll, and G. D. Aurbach (1977) Dopaminergic stimulation of cyclic AMP accumulation and parathyroid hormone release from dispersed bovine parathyroid cells. Proc. Natl. Acad. Sci. USA 74: 4210-4213.

Brown, J. H., and M. H. Makman (1972) Stimulation by dopamine of adenylate cyclase in retinal homogenates and of adenosine- $3^{\prime}: 5^{\prime}$ cyclic monophosphate formation in intact retina. Proc. Natl. Acad. Sci. USA 69: 539-543.

Brownstein, M., J. M. Saavedra, and M. Palkovits (1974) Norepinephrine and dopamine in the limbic system of the rat. Brain Res. 79: 431-436.

Burd, G. D., J. A. Paton, H. C. Hemmings, Jr., J. Heintz, and F. Nottebohm (1986) Dopamine innervation of newly-generated neurons in the forebrain of adult canaries. J. Histochem. Cytochem. (in press).

Cheramy, A., B. Leviel, and J. Glowinski (1981) Dendritic release of dopamine in the substantia nigra. Nature 289: 537-542.

Clement-Cormier, Y. C., and G. A. Robison (1977) Adenylate cyclase from various dopaminergic areas of the brain and the action of antipsychotic drugs. Biochem. Pharmacol. 26: 1719-1722.

Clement-Cormier, Y. C., J. W. Kehahian, G. L. Petzold, and P. Greengard (1974) Dopamine-sensitive adenylate cyclase in mammalian brain: A possible site of action of antipsychotic drugs. Proc. Natl. Acad. Sci. USA 71: 1113-1117.

Cleveland, D. W., S. G. Fischer, M. W. Kirschner, and U. K. Laemmli (1977) Peptide mapping by limited proteolysis in sodium dodecyl sulfate, and analysis by gel electrophoresis. J. Biol. Chem. 252: 11021106.

De Camilli, P., S. M. Harris, W. B. Huttner, and P. Greengard (1983) Synapsin I (Protein I), a nerve terminal-specific phosphoprotein: II. Its specific association with synaptic vesicles demonstrated by im- 
munocytochemistry in agarose-embedded synaptosomes. J. Cell Biol. 96: $1355-1373$.

Dimitriadis, G. J. (1979) Effect of detergents on antigen-antibody interactions. Anal. Biochem. 98: 445-451.

Dolphin, A., M. Hamont, and J. Bockaert (1979) The resolution of dopamine and $\beta_{1}$ - and $\beta_{2}$-adrenergic-sensitive adenylate cyclase activities in homogenates of cat cerebellum, hippocampus and cerebral cortex. Brain Res. 179: 305-317.

Ehinger, B. (1977) Synaptic connections of the dopaminergic retinal neurons. Adv. Biochem. Psychopharmacol. 16: 299-306.

Fuxe, K. (1965) Evidence for the existence of monoamine neurons in the central nervous system. IV. Distribution of monoamine nerve terminals in the central nervous system. Acta Physiol. Scand. Suppl. 247: $39-85$.

Glynn, I. M., and J. B. Chappell (1964) A simple method for the preparation of ${ }^{32} \mathrm{P}$-labeled adenosine triphosphate of high specific activity. Biochem. J. 90: 147-149.

Goelz, S. E., E. J. Nestler, B. Chehrazi, and P. Greengard (1981) Distribution of protein I in mammalian brain as determined by a detergent-based radioimmunoassay. Proc. Natl. Acad. Sci. USA 78: 2130 2134.

Goelz, S. E., E. J. Nestler, and P. Greengard (1985) Phylogenetic survey of proteins related to synapsin I and biochemical analysis of four such proteins from fish brain. J. Neurochem. 45: 63-72.

Greenwood, F. C., W. M. Hunter, and J. S. Glover (1963) The preparation of '3'I-labeled human growth hormone of high specific radioactivity. Biochem. J. 89: 114-123.

Groves, P. M. (1983) A theory of the functional organization of the neostriatum and the neostriatal control of voluntary movement. Brain. Res. Rev. 5: 109-132.

Gutman, Y., and P. Boonyaviroj (1979) Activation of adrenal medulla adenylate cyclase and catecholamine secretion. Naunyn Schmiedebergs Arch. Pharmacol. 307: 39-44.

Hemmings, H. C., Jr., P. Greengard, H. Y. Lim Tung, and P. Cohen (1984a) DARPP-32, a dopamine-regulated neuronal phosphoprotein, is a potent inhibitor of protein-phosphatase-1. Nature 310:503505 .

Hemmings, H. C., Jr., A. C. Nairn, D. W. Aswad, and P. Greengard (1984b) DARPP-32, a dopamine- and adenosine 3',5'-monophosphate-regulated phosphoprotcin enriched in dopamine-innervated brain regions. II. Purification and characterization of the phosphoprotein from bovine caudate nucleus. J. Neurosci. 4: 99-1 10.

Hemmings, H. C., Jr., A. C. Nairn, and P. Greengard (1984c) DARPP32 , a dopamine- and adenosine $3^{\prime}, 5^{\prime}$-monophosphate-regulated neuronal phosphoprotein. II. Comparison of the kinetics of phosphorylation of DARPP-32 and phosphatase inhibitor-1. J. Biol. Chem. 259 14491-14497.

Hemmings, H. C., Jr., K. R. Williams, W. H. Konigsberg, and P. Greengard (1984d) DARPP-32, a dopamine- and adenosine 3',5'-monophosphate-regulated neuronal phosphoprotein. I. Amino acid sequence around the phosphorylated threonine. J. Biol. Chem. 259: $14486-14490$

Hemmings, H. C., Jr., A. C. Nairn, and P. Greengard (1986a) Protein kinases and phosphoprotcins in the nervous system. In Neuropeptides in Neurologic and Psychiatric Disease, Research Publications of the Association for Research in Nervous and Mental Disorders, Vol. 64, J. B. Martin, ed., Raven Press, New York (in press).

Hemmings, H. C., Jr., E. J. Nestler, S. I. Walaas, C. C. Ouimet, and P. Greengard (1986b) Protein phosphorylation and neuronal function: DARPP-32, an illustrative example. In New Insights into Synaptic Function, G. M. Edelman, W. E. Gall, and W. W. Cowan, eds., Wiley, New York (in press).

Hemmings, H. C., Jr., S. I. Walaas, C. C. Ouimet, and P. Greengard (1986c) Dopamine receptors: Regulation of protein phosphorylation. In Receptor Biochemistry and Methodology. Vol. 9: Structure and Function of Dopamine Receptors, I. Creese and C. M. Fraser, eds., Liss, New York (in press)

Hökfelt, T., O. Johanssen, K. Fuxe, M. Goldstein, and D. Park (1977) Immunohistochemical studies on the localization and distribution of monoamine neuron systems in the rat brain. II. Tyrosine hydroxylase in the telencephalon. Med. Biol. 55: 21-40.

Holzbauer, M., and D. F. Sharman (1979) The distribution of dopamine in vertebrates. In The Neurobiology of Dopamine, A. S. Horn, J. Korf, and B. H. C. Westerink, eds., pp. 357-379, Academic, London.
Horn, A. S., A. C. Cuello, and R. J. Miller (1974) Dopamine in the mesolimbic system of the rat brain: Endogenous levels and the effect of drugs on the uptake mechanism and stimulation of adenylate cyclase activity. J. Neurochem. 22: 265-270.

Huttner, W. B., W. Schiebler, P. Greengard, and P. De Camilli (1983) Synapsin I (Protein I), a nerve terminal-specific phosphoprotien: III. Its association with synaptic vesicles studied in a highly-purified synaptic vesicle preparation. J. Cell Biol. 96: 1374-1388.

Ishikawa, K, T. Ott, and J. I. McGraugh (1982) Evidence for dopamine as a neurotransmitter in dorsal hippocampus. Brain Res. 232. 222-226.

Iversen, L. L. (1975) Dopamine receptors in the brain. Science 188; $1084-1089$.

Iversen, L. L. (1977) Catecholamine-sensitive adenylate cyclases in nervous tissue. J. Neurochem. 29: 5-12.

Juorio, A. V. (1973) The distribution of catecholamines in the hypothalamus and other brain areas of some lower vertebrates. J. Neurochem. 20: 641-645.

Kaczmarek, L. K., K. R. Jennings, R. Strumwasser, A. C. Nairn, U. Walter, F. D. Wilson, and P. Greengard (1980) Microinjection of catalytic subunit of cyclic AMP-dependent protein kinase enhances calcium action potentials of bag cell neurons in cell culture. Proc. Natl. Acad. Sci. USA 77: 7487-7491.

Kebabian, J. W., and D. B. Calne (1979) Multiple receptors for dopamine. Nature 277: 93-96.

Kebabian, J. W., and P. Greengard (1971) Dopamine-sensitive adenyl cyclase: Possible role in synaptic transmission. Science 174: 13461349.

Kebabian, J. W., and J. M. Saavedra (1976) Dopamine-sensitive adenylate cyclase occurs in a region of substantia nigra containing dopaminergic dendrites. Science 193: 683-685.

Kebabian, J. W., G. L. Petzold, and P. Greengard (1972) Dopaminesensitive adenylate cyclase in caudate nucleus of rat brain, and its similarity to the "dopamine receptor." Proc. Natl. Acad. Sci. USA 69: 2145-2149.

Kessler, S. W. (1975) Rapid isolation of antigens from cells with a staphylococcal protein A-antibody adsorbent: Parameters of the interaction of antibody-antigen complexes with protein A. J. Immunol. 115: 1617-1624.

King, M. M., C. Y. Huang, P. B. Chock, A. C. Nairn, H. C. Hemmings, Jr., K.-F. J. Chan, and P. Greengard (1984) Mammalian brain phosphoproteins as substrates for calcineurin. J. Biol. Chem. 259:80808083.

Köhler, G., and C. Milstein (1975) Continuous cultures of fused cells secreting antibody of predefined specificity. Nature 256: 495-497.

Kramer, S. G. (1971) Dopamine: A retinal neurotransmitter. Invest. Ophthalmol. 71: 438-452.

Krieger, N. R., J. S. Kauer, G. M. Shepherd, and P. Greengard (1977) Dopamine-sensitive adenylate cyclase within laminae of the olfactory tubercle. Brain Res. 131: 303-312.

Laemmli, U. K. (1970) Cleavage of structural proteins during the assembly of the head of bacteriophage T4. Nature 227: 680-685.

Lindvall, O., and A. Björklund (1974) The organization of the ascending catecholamine neuron systems in the rat brain as revealed by the glyoxylic acid fluorescent method. Acta Physiol. Scand. Suppl. 412: $1-48$.

Lindvall, O., and A. Björklund (1978) Organization of catecholamine neurons in the rat central nervous system. In Handbook of Psychopharmacology, Vol. 9, L. L. Iversen, S. D. Iversen, and S. H. Snyder, eds., pp. 139-231, Plenum, New York.

Lindvall, O., and A. Björklund (1979) Dopaminergic innervation of the globus pallidus by collaterals from the nigrostriatal pathway. Brain Res. 172: 169-173.

Lindvall, O., A. Björklund, R. Y. Moore, and U. Stenevi (1974) Mesencephalic dopamine neurons projecting to neocortex. Brain Res. 81 : 325-331.

Lindvall, O., A. Björklund, and I. Divac (1978) Organization of catecholamine neurons projecting to the frontal cortex in the rat. Brain Res. 142: 1-24.

Llinàs, R., T. McGuinness, C. S. Leonard, M. Sugimori, and P. Greengard (1985) Intraterminal injection of synapsin I or of calcium/ calmodulin-dependent protein kinase II alters neurotransmitter release at the squid giant synapse. Proc. Natl. Acad. Sci. USA 82: 3035-3039.

Martres, M.-P., M.-L. Bouthenet, N. Sales, P. Sokoloff, and J.-C. 
Schwartz (1985) Widespread distribution of brain dopamine receptors evidenced with [ $\left.{ }^{125} I\right]$ iodosulpiride, a highly selective ligand. Science 228: 752-755.

Miller, R. J., and J. McDermed (1979) Dopamine-sensitive adenylate cyclase. In The Neurobiology of Dopamine, A. S. Horn, J. Korf, and B. H. C. Westerink, eds., pp. 159-177, Academic, London.

Moore, R. Y., and F. E. Bloom (1978) Central catecholamine neuron systems: Anatomy and physiology of the dopamine systems. Annu. Rev. Neurosci. 1: 129-169.

Nairn, A. C., H. C. Hemmings, Jr., and P. Greengard (1985) Protein kinases in the brain. Annu. Rev. Biochem. 54: 931-976.

Nathanson, J. A. (1980) $\beta$-Adrenergic-sensitive adenylate cyclase in choroid plexus: Properties and cellular localization. Mol. Pharmacol. 18: 199-209.

Nestler, E. J., S. I. Walaas, and P. Greengard (1984) Neuronal phosphoproteins: Physiological and clinical implications. Science 225: $1357-1364$

Nimmo, G. A., and P. Cohen (1978) The regulation of glycogen metabolism. Purification and characterization of protein phosphatase inhibitor-1 from rabbit skeletal muscle. Eur. J. Biochem. 87: 341351.

Ouimet, C. C., H. C. Hemmings, Jr., and P. Greengard (1983) Light and electron microscopic immunocytochemistry of a dopamine- and cyclic AMP-regulated phosphoprotein (DARPP-32) in rat brain. Soc. Neurosci. Abstr. 9: 82.

Ouimet, C. C., P. E. Miller, H. C. Hemmings, Jr., S. 1. Walaas, and P. Greengard (1984) DARPP-32, a dopamine- and adenosine 3', 5'monophosphate-regulated phosphoprotein enriched in dopamine-innervated brain regions. III. Immunocytochemical localization. J. Neurosci. 4: 111-124.

Parent, A. (1979) Monoaminergic systems of the brain. In Biology of the Reptilia, C. Gans, R. G. Northcutt, and P. Ulinski, eds., pp. 247285, Academic, London.

Parent, A., D. Poitras, and L. Dube (1984) Comparative anatomy of central monoaminergic systems. In Handbook of Chemical Neuroanatomy. Vol. 2: Classical Transmitters in the CNS, Part I, A. Björklund and T. Hökfelt, eds., pp. 409-439, Elsevier, Amsterdam.

Peterson, G. L. (1977) A simplification of the protein assay of Lowry et al., which is more generally applicable. Anal. Biochem. 83: 346356.

Phillipson, O. T., and A. S. Horn (1976) Substantia nigra of the rat contains a dopamine sensitive adenylate cyclase. Nature 261: 418420.

Premont, J., A. M. Thierry, J. P. Tassin, J. Glowinski, G. Blanc, and J. Bockaert (1976) Is the dopamine-sensitive adenylate cyclase in the rat substantia nigra coupled with "autoreceptors?" FEBS Lett. 68 : 99-104.

Reader, T. A., P. Masse, and J. de Champlain (1979) The intracortical distribution of norepinephrine, dopamine, and serotonin in the cerebral cortex of the cat. Brain Res. 177: 499-513.

Reiner, A., S. E. Brauth, and H. J. Karten (1984) Evolution of the amniote basal ganglia. Trends Neurosci. 7: 320-325.

Schmitt, F. O. (1984) Molecular regulators of brain function: A new view. Neuroscience 13: 991-1001.

Serck-Hanssen, G., T. Christoffersen, J. Mørland, and J. B. Osnes (1972) Adenyl cyclase activity in bovine adrenal medulla. Eur. J. Pharmacol. 19: 297-300.

Shulman, M., C. D. Wilde, and G. Köhler (1978) A better cell line for making hybridomas secreting specific antibodies. Nature 276: 269-270.

Spano, P. F., G. Di Chiara, G. C. Tonon, and M. Trabucchi (1976) A dopamine-stimulated adenylate cyclase in rat substantia nigra. J. Neurochem. 27: 1565-1568.
Stoof, J. C.,, and J. W. Kebabian (1984) Two dopamine receptors: Biochemistry, physiology and pharmacology. Life Sci. 35: 2281-2296.

Stone, R. A., A. M. Laties, C. C. Ouimet, H. C. Hemmings, Jr., and P. Greengard (1985) Dopamine receptor (D-1) regulated phosphoprotein in the non-pigmented ciliary epithelium. Invest. Ophthalmol. Vis. Sci. (Suppl.) 26: 109.

Stone, R. A., A. M. Laties, H. C. Hemmings, Jr., C. C. Ouimet, and P. Greengard (1986) DARPP-32, a dopamine-regulated phosphoprotein, in the ciliary epithelium of the eye. J. Histochem. Cytochem. (in press).

Tassin, J. P., J. Bockaert, G. Blanc, L. Stinus, A. M. Thierry, S. Lavielle, J. Premont, and J. Glowinski (1978) Topographical distribution of dopaminergic innervation and dopaminergic receptors of the anterior cerebral cortex of the rat. Brain Res. 154: 241-251.

Towbin, H., T. Staehelin, and J. Gordon (1979) Electrophoretic transfer of proteins from polyacrylamide gels to nitrocellulose sheets: Procedure and some applications. Proc. Natl. Acad. Sci. USA 76: 43504354.

Townsend, J. B., D. M. Ziedonis, R. M. Bryan, R. W. Brennan, and R. B. Page (1984) Choroid plexus blood flow: Evidence for dopaminergic influence. Brain Res. 290: 165-169.

Ueda, T., and P. Greengard (1977) Adenosine 3':5'-monophosphateregulated phosphoprotein system of neuronal membranes. I. Solubilization, purification, and some properties of an endogenous phosphoprotein. J. Biol. Chem. 252: 5155-5163.

Ungerstedt, U. (1971) Stereotoxic mapping of the monoamine pathways in the rat brain. Acta. Physiol. Scand. Suppl. 367: 1-48.

Van Steirteghem, A. C., M. H. Zweig, and A. N. Schechter (1978) Radioimmunoassay of creatine kinase isoenzymes in human serum: Isoenzyme MM. Clin. Chem. 24: 414-421.

Verney, C., M. Baulac, B. Berger, C. Alvarez, A. Vigny, and K. B. Helle (1985) Morphological evidence for a dopaminergic terminal field in the hippocampal formation of young and adult rat. Neuroscience 14 : 1039-1052.

Versteeg, D. H. G., J. van der Gugten, W. De Jong, and M. Palkovits (1976) Regional concentrations of noradrenaline and dopamine in rat brain. Brain Res. 113: 563-574.

Walaas, S. I., and P. Greengard (1984) DARPP-32, a dopamine- and adenosine $3^{\prime}, 5^{\prime}$-monophosphate-regulated phosphoprotein enriched in dopamine-innervated brain regions. I. Regional and cellular distribution in rat brain. J. Neurosci. 4: 84-98.

Walaas, S. I., D. W. Aswad, and P. Greengard (1983a) A dopamineand cyclic AMP-regulated phosphoprotein enriched in dopamine innervated brain regions. Nature 301: 69-71.

Walaas, S. I., A. C. Nairn, and P. Greengard (1983b) Regional distribution of calcium- and cyclic AMP-regulated protein phosphorylation systems in mammalian brain. I. Particulate systems. J. Neurosci. 3: 291-301.

Walaas, S. I., A. C. Naim, and P. Greengard (1983c) Regional distribution of calcium- and cyclic AMP-regulated protein phosphorylation systems in mammalian brain. II. Soluble systems. J. Neurosci. 3: 302-311.

Walaas, S. I., C. C. Ouimet, H. C. Hemmings, Jr., and P. Greengard (1986) DARPP-32, a dopamine-regulated neuronal phosphoprotein in the basal ganglia. In Dopamine Systems and Their Regulation, G. D. Woodruff, ed., MacMillan, London (in press).

Williams, K. R., H. C. Hemmings, Jr., M. B. LoPresti, W. H. Konigsberg, and P. Greengard (1986) DARPP-32, a dopamine- and cyclic AMP-regulated neuronal phosphoprotein: Primary structure and homology with protein phosphatase inhibitor-1. J. Biol. Chem. 261: 1890-1903. 